Article

\title{
Detection and Characterisation of Eemian Marine Tephra Layers within the Sapropel S5 Sediments of the Aegean and Levantine Seas
}

\author{
Christopher Satow ${ }^{1, *}$, Katharine M. Grant ${ }^{2}$, Sabine Wulf ${ }^{3}$, Hartmut Schulz ${ }^{4}$, Addison Mallon ${ }^{5}$, \\ Ian Matthews ${ }^{5}$ and John Lowe ${ }^{5}$ \\ 1 Department of Social Sciences, Oxford Brookes University, Headington Road, Oxford OX3 0BP, UK \\ 2 Research School of Earth Sciences, The Australian National University, Canberra ACT 2601, Australia; \\ katharine.grant@anu.edu.au \\ 3 School of the Environment, Geography and Geosciences, University of Portsmouth, Buckingham Building, \\ Lion Terrace, Portsmouth PO1 3HE, UK; sabine.wulf@port.ac.uk \\ 4 Department of Geosciences, University of Tübingen, Hölderlinstr. 12, 72074 Tübingen, Germany; \\ hartmut.schulz@uni-tuebingen.de \\ 5 Centre for Quaternary Research, Department of Geography, Royal Holloway University of London, \\ London TW20 OEX, UK; addison.mallon.2016@live.rhul.ac.uk (A.M.); i.p.matthews@rhul.ac.uk (I.M.); \\ j.lowe@rhul.ac.uk (J.L.) \\ * Correspondence: csatow@brookes.ac.uk
}

Received: 16 December 2019; Accepted: 19 February 2020; Published: 13 March 2020

\begin{abstract}
The Eemian was the last interglacial period ( 130 to $115 \mathrm{ka} B \mathrm{BP})$ to precede the current interglacial. In Eastern Mediterranean marine sediments, it is marked by a well-developed and organic-rich "sapropel" layer (S5), which is thought to reflect an intensification and northward migration of the African monsoon rain belt over orbital timescales. However, despite the importance of these sediments, very little proxy-independent stratigraphic information is available to enable rigorous correlation of these sediments across the region. This paper presents the first detailed study of visible and non-visible (cryptotephra) layers found within these sediments at three marine coring sites: ODP Site 967B (Levantine Basin), KL51 (South East of Crete) and LC21 (Southern Aegean Sea). Major element analyses of the glass component were used to distinguish four distinct tephra events of Santorini (e.g., Vourvoulos eruption) and possible Anatolian provenance occurring during the formation of S5. Interpolation of core chronologies provides provisional eruption ages for the uppermost tephra (unknown Santorini, $121.8 \pm 2.9 \mathrm{ka}$ ) and lowermost tephra (Anatolia or Kos/Yali/Nisyros, $126.4 \pm 2.9 \mathrm{ka}$ ). These newly characterised tephra deposits have also been set into the regional tephrostratigraphy to illustrate the potential to precisely synchronise marine proxy records with their terrestrial counterparts, and also contribute to the establishment of a more detailed volcanic history of the Eastern Mediterranean.
\end{abstract}

Keywords: quaternary; palaeoceanography; Europe; sedimentology-marine cores; tephrochronology; Eemian

\section{Introduction}

Tephra (volcanic ash) layers can potentially enable the precise alignment of sediment records to resolve the relative timings of palaeoenvironmental events between a wide range of terrestrial and marine archives [1-3]. If they can be dated directly, these markers provide independent checks on age models based on alternative dating methods [4-6]. Records preserving several superimposed tephra layers together constitute a tephrostratigraphy which can contribute to a more detailed understanding of volcanic histories [7-12]. 
The development of an Eastern Mediterranean marine tephrostratigraphy, which includes not only Italian but also Aegean Arc source volcanoes (e.g., Santorini, Kos, Nisyros, Yali), is still in its infancy. Data available from the Sea of Marmara and the northern Aegean Sea only extend back through the last $\sim 80$ kyrs and rarely include cryptotephra data [13-16]. Longer sediment sequences from the southern Aegean Sea and the Levantine Basin have only occasionally been studied in terms of their(crypto) tephra content despite the favourable downwind position of these sites with respect to Quaternary active volcanoes and their importance for palaeoceanographic research [17]. For example, marine cores in this area have provided detailed evidence of orbital-scale African monsoon variability over at least the last $3 \mathrm{Ma}$, forced by changes in Nile run-off into the basin [18-22], as well as centennial- to millennial-scale variations in sea surface temperature and circulation modes throughout the eastern Mediterranean [23-29]. Hence, independent dating and linking of these palaeo-records via (crypto)tephras is crucial.

The application of tephrochronological studies has been spurred to some extent by improved methods for recovering and analysing non-visible ash (cryptotephra) layers from sediment sequences worldwide. This has greatly extended the traceable "footprints" of some tephra isochrons and helped to extend or refine regional tephrostratigraphic frameworks (or "lattices"), particularly for the Late Quaternary in the Mediterranean [5,17,30-33].

The development of a tephra framework for the Mediterranean Sea started with the first recovery of deep-sea cores from the Ionian and Levantine Seas in the late 1940s and has been updated ever since $[13,14,34-40]$. Detailed marine tephrostratigraphies for Central Mediterranean (Italian) volcanoes were compiled for the last 200 kyrs from Tyrrhenian, Ionian and Adriatic Sea cores and the first cryptotephra studies were also undertaken in this region [5,8,30,41-47].

The Aegean and Levantine Seas are situated downwind from volcanoes in the Aegean Arc (Methana, Milos, Santorini, Kos, Yali, Nisyros), and, further to the west, on the Italian peninsula (Campanian and Roman Provinces) and islands (Etna, Aeolian Islands, Pantelleria) (Figure 1) -all of which were frequently active during the Late Quaternary (see [48] and references therein). The Levantine Sea in particular can also receive tephra from the North from highly active Western and Central Anatolian volcanoes (Acigöl, Hasan Dag, Erciyes Dag) (Figure 1). However, so far, very few tephra layers have been characterised in the eastern sector of the Mediterranean Basin and tephra studies have, therefore, been underexploited in the construction of volcanic histories. In the Levantine Sea, the known tephrostratigraphical record consists only of an Early Holocene tephra thought to originate from the Ericyes Dag stratovolcano in Central Anatolia [49], the 22 ka Cape Riva tephra from Santorini [50,51], and the $161 \mathrm{ka}$ Kos Plateau Tuff (KPT; [50,52,53]). All these tephras form visible layers in the marine sediment records, and this sector of the Mediterranean has not previously been investigated for the presence of cryptotephra layers. The only published marine cryptotephra record in the Eastern Mediterranean Sea is derived from core LC21 in the southern Aegean Sea [17]. This core encompasses the last 160 kyrs and has been used for high-resolution palaeoceanographic reconstructions $[18,21-23,26,27,54]$. A detailed study identified nine visible tephras and eight cryptotephra layers in core LC21 with provenances from Italian and Aegean Arc volcanoes [17], demonstrating the potential for tephra to correlate the region's marine sediment cores.

Here, we present updated (crypto)tephra results from core LC21 and two other deep-sea cores; M40/4-67 (GeoTÜ-KL51) from the southeastern Aegean Sea and Ocean Drilling Project (ODP) Site 967B from the central Levantine Basin (Supplementary Materials 1 and 2). These cores hold sapropel sediments deposited during the Eemian (last) interglacial period ( 130-115 ka) (sapropels S3-S5).

Sapropel S5 is represented in numerous sediment cores throughout the eastern Mediterranean and dated to between 128.3 and $121.5 \mathrm{ka}$ [21]. It is the best developed (often annually laminated) sapropel of the last glacial/interglacial cycle (see [18] and references therein). Sapropel boundaries are frequently used as isochrons to synchronise eastern Mediterranean sediment records, but these can be blurred by post-depositional oxidation/reduction at the top/base of each layer. Furthermore, the exact onset and cessation of sapropel formation at each site depends on the development of 
benthic anoxia, which in turn depends on water depth, vertical mixing, and carbon export. These factors may result in differences of a few centuries between sites, for the start and end of sapropel formation [55]. Uncertainties ( $\pm 2 \mathrm{ka}$ ) on current dates for the start and end of sapropels S3-S5 [21] are large enough to accommodate these centennial geographic differences in the timing of sapropel formation. Nonetheless, the tephra layers reported here may prove particularly valuable for clarifying centennial- to millennial-scale changes during the Eemian in this climatically sensitive region.

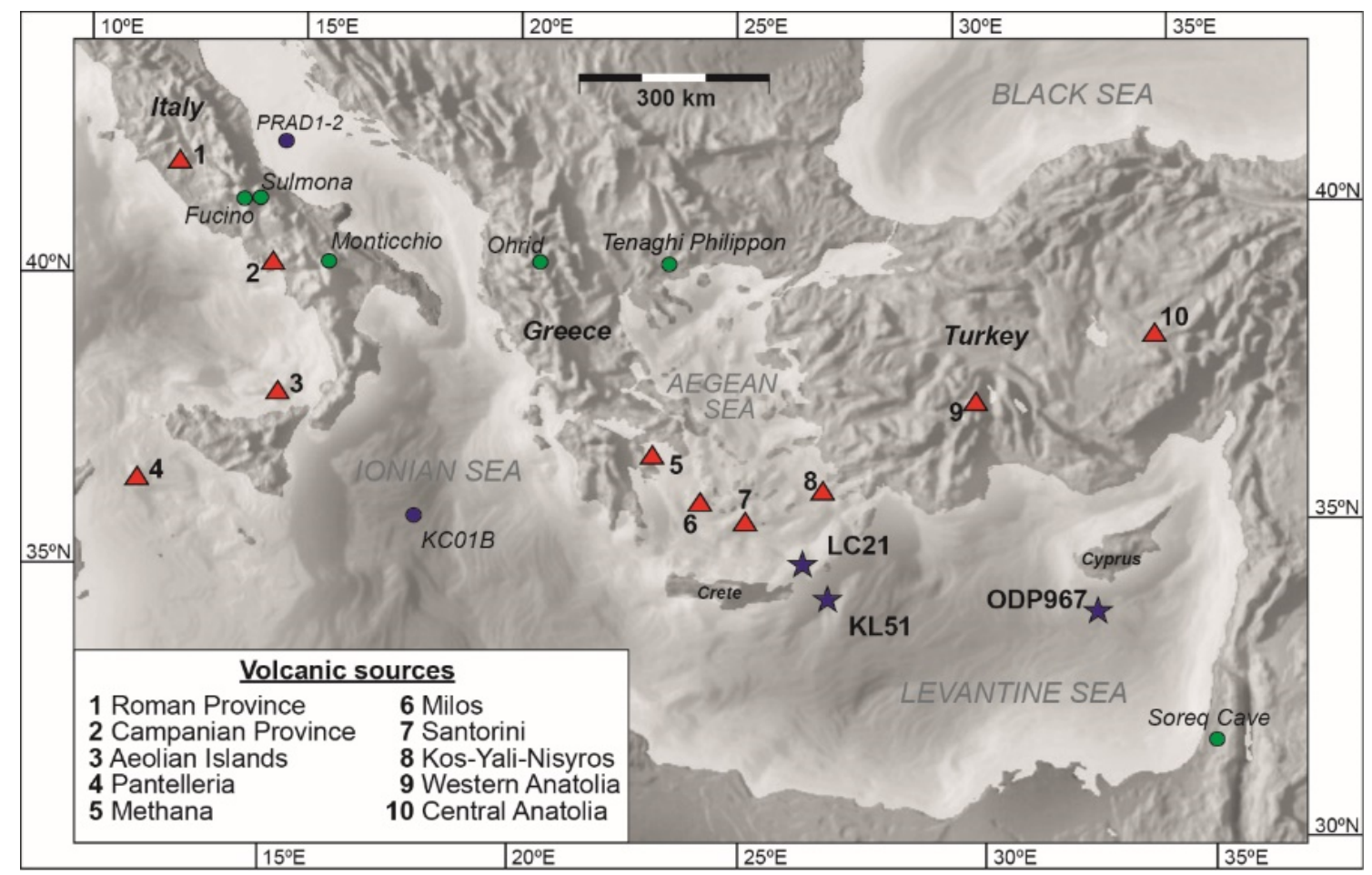

Figure 1. Map of the Eastern Mediterranean showing the locations of marine cores sampled in this study (purple stars: LC21, KL51 and ODP967), the potential tephra source regions (red triangles: numbered 1-10), and other locations mentioned in the text (purple circles are marine sediment cores, green circles are terrestrial environmental records).

Where the geochemistry of a tephra layer can be matched to a proximal volcanic deposit, the date derived for the tephra layer can also be used to apply age constraints to the development and activity of a volcanic system [56,57]. This is sometimes the only way to define dates for volcanoes, particularly those with magmatic compositions which are not conducive to radiometric dating. For example, in the Aegean, dates for eruptions of Yali [17], Nisyros [58] and Santorini [59] are only known from the correlation of proximal volcanic stratigraphies to tephra deposits in marine sediment cores. The tephra deposits described here, therefore, provide a new opportunity to define eruption dates for the volcanic systems of the Eastern Mediterranean.

\section{Materials and Sample Locations}

Sample names in this study are the name of the sediment core (and section if relevant) followed by the depth (in $\mathrm{cm}$ ) below the sea floor of the sample. This follows the convention set by $[5,10,17,30]$ and allows easy correspondence with other studies [60,61].

\subsection{ODP Site 967}

ODP Site 967B (hereafter, ODP967B-2H1) is located $\sim 60 \mathrm{~km}$ south of Cyprus at a water depth of $2555 \mathrm{~m}\left(34^{\circ} 04^{\prime} \mathrm{N}, 32^{\circ} 43^{\prime} \mathrm{E}\right.$; Figure 1; [62,63]). This study used samples obtained from core Section 2H1 from Hole B of ODP967, which includes sapropel S5 [64] (Figure 2), as well as over- and underlying 
Foraminifera-rich, nannofossil ooze and clays; bioturbation in these sediments is minor. A $2 \times$ $2 \times 150 \mathrm{~cm}$ u-channel was extracted at the ODP core repository at MARUM (Centre for Marine Environmental Sciences, University of Bremen, Bremen, Germany) after X-ray fluorescence (XRF) scanning analysis of the core section [22]. The sediment was then sampled contiguously throughout the sapropel S5 unit, between core section depths of 100 and $140 \mathrm{~cm}$, initially at $5 \mathrm{~cm}$ intervals and subsequently at $1 \mathrm{~cm}$ resolution in those parts of the core in which tephra shards were found (Figure 2). Full details of the XRF scanning methods are presented in [22].

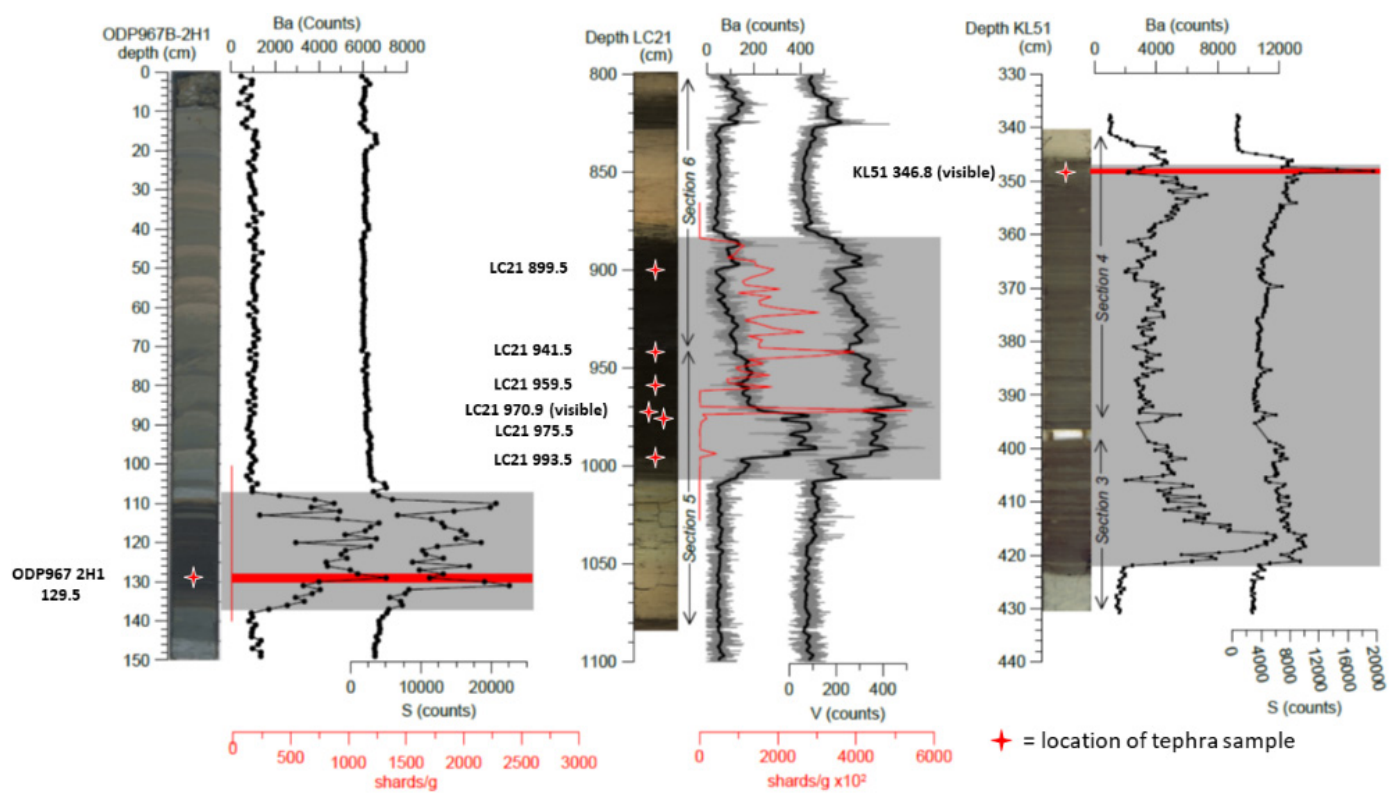

Figure 2. Tephra samples (red stars) taken from sapropel S5 in Eastern Mediterranean marine cores ODP967B-2H1, LC21, and KL51. Scanning X-ray fluorescence (XRF) profiles and grey shading indicate the position of S5, after [21,22] and [60]. Ba, S and V are shown because they best delineate the depth range of the sapropel. Note that no Sulphur data are available for LC21, so the similarly redox-sensitive Vanadium is used instead. A 21-point running average (black) is superimposed on the raw data for LC21. Glass shards were counted in the cryptotephra layers of ODP 967B (vertical red line indicates the interval sampled, horizontal red line indicates location and concentration of the single sample containing shards; the cryptotephra deposit) and LC21 (cryptotephra shard concentrations shown by red line), whereas KL51 contains only a $5 \mathrm{~mm}$ thick visible tephra layer (red horizontal line); no cryptotephra investigation was undertaken on this core. LC21 also contains a $2 \mathrm{~mm}$ thick visible tephra layer at $970.9 \mathrm{~cm}$ depth, previously described in [17]. Down-core depths are shown for LC21 and KL51, but as ODP Site 967B comprises four drill holes (hence composite down-hole depths) the section depth is shown here to allow easy relocation of samples and comparison to other studies [61].

\subsection{Site LC21}

Core LC21 (Figures 1 and 2) was collected off the north coast of Crete $\left(35^{\circ} 66^{\prime} \mathrm{N}, 26^{\circ} 58^{\prime} \mathrm{E}\right)$ in 1995 during the Marion Dufresne 81 cruise, using heavy piston coring at a water depth of $1522 \mathrm{~m}[65,66]$. The results of the only tephra study of this core, which found an abundance $\left(>3000\right.$ shards $\left.\mathrm{g}^{-1}\right)$ of cryptotephra throughout the upper part of sapropel S5 between 8.755 and $9.575 \mathrm{mbsf}$ and a visible tephra layer within S5 at a core depth of at 9.709 mbsf (sample LC21 970.9-visible), are reported in [17]. Both of these tephra layers were attributed by [17] to activity of the Santorini volcano on the basis of major and trace element measurements and comparison with a proximally derived database of [48]. However, that study did not include detailed sampling and chemical characterisation of the cryptotephra found in the upper part of the sapropel except for one sample that derived from the base of this tephra interval at $9.575 \mathrm{mbsf}$ (sample LC21 957.5). This is addressed in the present study through complete resampling of the $\mathrm{S} 5$ sediment unit within LC21, with a higher resolution $(2 \mathrm{~cm})$ sampling 
interval than that $(5 \mathrm{~cm})$ adopted by [17] and also by the production and presentation of additional geochemical data. The results of XRF scanning analysis of the core (Figure 2) were published by [21].

\subsection{Site KL51}

Site M40/4-67 (GeoTÜ-KL51, hereafter KL51) is the best preserved of a group of METEOR cores (M40/4 SL67, M51/3 SL103, M51/3 SL104; [60,67]) collected from southeast of Crete (34 $\left.49^{\prime} \mathrm{N}, 2^{\circ} 17^{\prime} \mathrm{E}\right)$ in a water depth of $\sim 2150 \mathrm{~m}$-all of which display the S5 sapropel horizon (Figures 2 and 3). In KL51, S5 is located at a down-core depth of $\sim 344.5-421.9 \mathrm{~cm}$ below the seafloor. At $\sim 77 \mathrm{~cm}$ thick, it is one of the thickest sapropels recorded for the Eastern Mediterranean (Figure 3) and is characterised by laminated diatomaceous ooze which has been intensively studied by [60]. Although this core was not sampled for cryptotephra, a $\sim 5 \mathrm{~mm}$ thick, dark-grey volcanic ash layer, visible to the naked eye, has been previously described but not yet chemically characterised within the upper part of exceptionally well-preserved S5 sediments in core KL51 [60] (Figures 2 and 3). In this study, we report the first electron probe microanalysis (EPMA) results for this ash layer, obtained from shards extracted from an original core depth interval of 346.3-346.8 cm. High-resolution (1 mm interval) XRF scanning and spectrophotometric data were also obtained from the archived core halves of core Section 4 $(294.5-395.5 \mathrm{~cm})$ and $3(395.5-496.5 \mathrm{~cm})$, which were still intact after cold storage of more than 20 years at Tübingen and Bremen. A GeoB smart-CIS 1600 Line Scanner and camera system (Schäfter \& Kirchhoff GMbH, Hamburg, Germany) was used to record sedimentary changes in core KL51 linked to varve/laminae formation and to tephra deposition (see Supplementary Material 3). However, the core depth scales had to be corrected by up to $2.0 \mathrm{~cm}$ (Figure 3) due to shrinkage. As a result, the interval previously sampled for EPMA is shifted down by two centimetres, i.e., to $348.3-348.8 \mathrm{~cm}$ in core KL51. Using this revised depth scale, XRF elemental counts were generated at $4 \mathrm{~mm}$ depth resolution for $\mathrm{Ba}$ and $S$ (Figure 2) to provide additional stratigraphic context.

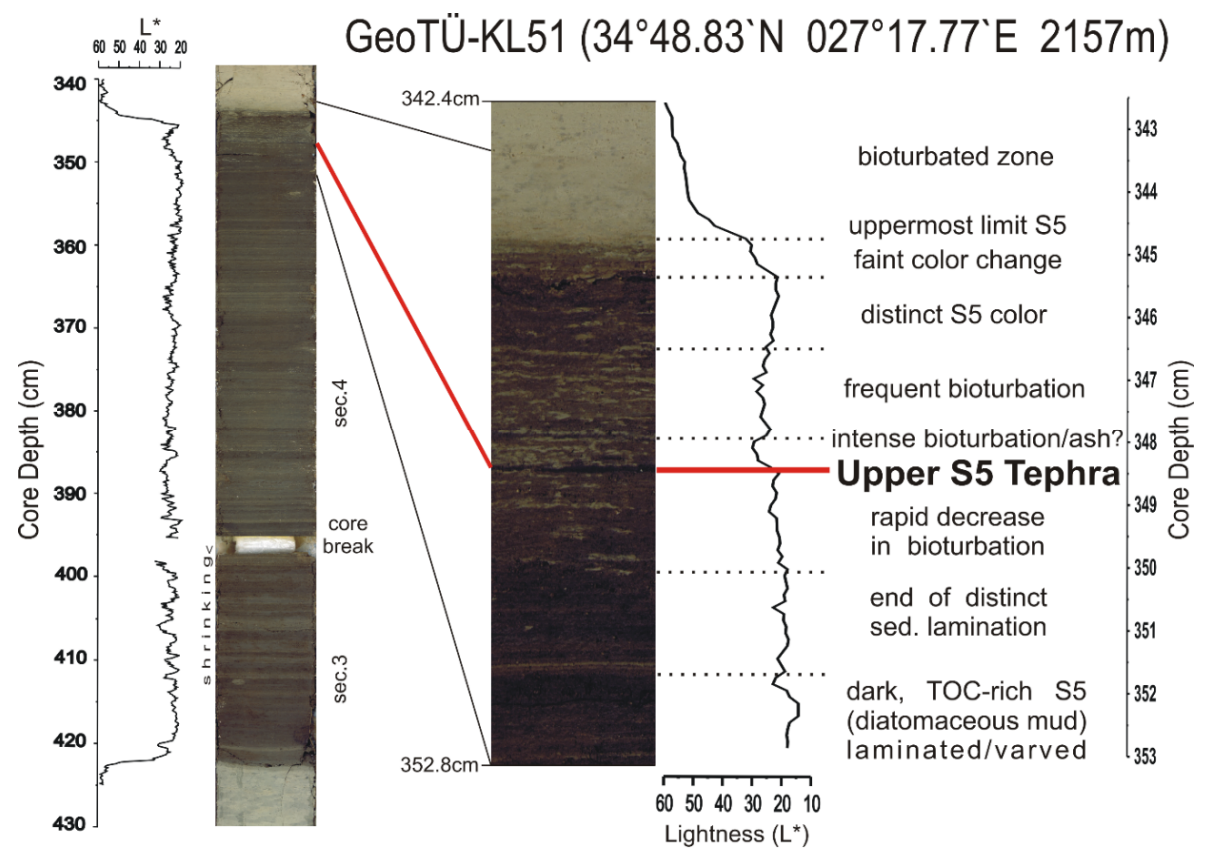

Figure 3. Detailed core photograph and sedimentological features of core KL51 showing the position and preservation of the KL51 S5 tephra layer and the correction for shrinkage in the core between Sections 3 and 4. The KL51 S5 tephra layer is located at an original depth in the core of 346.3-346.8 cm (see [60]) which after correction for core shrinkage, becomes $348.3-348.8 \mathrm{~cm}$. This study uses the original depth of 346.3-346.8 cm to retain consistency with previous studies [60]. 
Importantly, the proxy stratigraphies of S5 in all three cores (ODP967B in [22]; LC21 in [54], and KL51 in [60]) investigated here are considered to be intact and affected only by minor bioturbation. The known sedimentology of the cores does not, therefore, indicate significant reworking.

\section{Analytical Methods}

Analytical methods for each core are presented separately, as each was investigated independently by different research teams.

\subsection{Tephra Sample Preparation (Cores ODP967B and LC21)}

Samples of $2 \mathrm{~cm}$ (core LC21) and $1 \mathrm{~cm}$ (core ODP967B) thickness from throughout the depth of sapropel S5 (Figure 2) were dried and weighed in order to subsequently determine the shard counts per gram of dry sediment. Then the samples were heated in a furnace for $3.5 \mathrm{~h}$ at $550^{\circ} \mathrm{C}$ to remove organic material and soaked in $10 \% \mathrm{HCl}$ for $30 \mathrm{~min}$ to dissolve carbonates. The residues were sieved over 125 and $25 \mu \mathrm{m}$ meshes to filter large detrital particles and clays, then floated in diluted sodium polytungstate, first at a density of $1.95 \mathrm{~kg} \mathrm{~L}^{-1}$ and then at $2.55 \mathrm{~kg} \mathrm{~L}^{-1}$, to isolate the volcanic glass shards from organic and other mineral matter. The floated material was mounted onto a slide using Euparal and examined for cryptotephra shards under a high-power $(\times 200$ or $\times 400)$ microscope. Samples containing cryptotephra shards were then resampled at $1 \mathrm{~cm}$ resolution (ODP967B) and $2 \mathrm{~cm}$ resolution (LC21). The same procedures were adopted for isolating these repeat samples but combustion of the samples was avoided as this can distort their chemical composition. Instead, to remove organic matter, the samples were floated twice in sodium polytungstate at a density of $1.95 \mathrm{~kg} \mathrm{~L}^{-1}$, as described in [68]. The resampling was undertaken in order to refine the positions of peak shard concentrations from which shards were extracted for chemical analysis; the resulting counts (per gram of dry sediment) are shown in Figure 2.

Cryptotephra samples were extracted from horizons in which peaks in shard concentrations were recorded (Figure 2). Defining a peak in shard concentrations for cryptotephra sampling is somewhat subjective and so a consistent methodology was employed here. A peak was defined where the concentration of shards per gram was at least $30 \%$ greater than that of the sample above or below, or where shards were present in a sample, but none were found in the adjacent samples above or below. Following these criteria, three samples were taken from the shard-rich upper part of the S5 unit. These were targeted on the lowermost, largest and uppermost of the concentration peaks recorded for this interval (Figure 2) with the aim to capture the geochemistry of the first, largest and last inputs of tephra in this interval.

The extracted shards were then mounted onto pre-flattened (to within $30 \mu \mathrm{m}$ ) SpeciFix-40 resin stubs (Struers Inc., Cleveland, OH, USA) with the aid of a micro-manipulator and syringe to ensure a pure glass sample, prior to submission for EPMA. Shards from the visible tephra layer in core LC21 at $970.9 \mathrm{~cm}$ depth were extracted using a spatula and mounted directly onto a pre-flattened (to within $30 \mu \mathrm{m})$ SpeciFix-40 resin stub (see [17]).

\subsection{Visible Tephra Preparation (Core KL51)}

A sample of the visible tephra layer in core KL51 at 346.3-346.8 cm depth was treated with a 10\% $\mathrm{HCl}$ solution to remove carbonates and subsequently sieved to isolate the $20-100 \mu \mathrm{m}$ size fraction. Bulk tephra material of this fraction was then dried with Ethanol, embedded in Araldite $\subseteq 2020$ resin (DGE, Alphen aan den Rijn, Netherlands) on a $48 \times 28 \mathrm{~mm}$ glass slide, sectioned and polished for EPMA measurement targeted on glass shards. 


\subsection{Electron Probe Microanalysis (EPMA)}

\subsubsection{Samples from Cores LC21 and ODP967}

Major element compositions of (crypto)tephras from cores LC21 and ODP967B were measured at the Research Laboratory for Archaeology and the History of Art, University of Oxford, Oxford, UK, using a 4 spectrometer JEOL JXA-8600 Superprobe (JEOL, Freising, Germany). The accelerating voltage was $15 \mathrm{kV}$ with a defocused beam of $10 \mu \mathrm{m}$ diameter and a current of $6 \mathrm{nA}$ in order to avoid alkali migration. Count times were $30 \mathrm{~s}$ on each peak, except for $\mathrm{Na}$ (12 s, and measured first), $\mathrm{P}$ and $\mathrm{Mn}(60 \mathrm{~s})$, and $\mathrm{Cl}(50 \mathrm{~s})$. Off-peak background counting times were half those of the peaks. Max Planck Institute standards StHs6/80 and ATHO-G [69] were analysed at the start, during and at the end of the run to monitor analysis accuracy and precision. Analytical data were filtered to remove analyses of non-vitreous material as well as those analyses with analytical totals lower than $90 \%$ (water contents for rhyolitic glass shards can reach $9-10 \%$ through a combination of magmatic water and alteration [50,70]). All analyses were normalised to $100 \%$, to account for variable volatile concentrations. Both raw data and $100 \%$ normalised (volatile-free) data are provided in the supplementary information (Supplementary Materials 1 and 2).

\subsubsection{Sample from Core KL51}

Glass shards from the visible tephra in core KL51 at 346.3-346.8 cm depth was analysed at the German Research Centre for Geosciences (GFZ) in Potsdam, Germany using a JEOL JXA-8250 Electron Microprobe with 5 spectrometers (JEOL, Freising, Germany). The analytical setup used a $15 \mathrm{kV}$ accelerating voltage, $10 \mathrm{nA}$ beam current, and a $10 \mu \mathrm{m}$ defocused beam. Count times per element were $20 \mathrm{~s}$ except for sodium analysed first at $10 \mathrm{~s}$. The rhyolitic Lipari obsidian [71,72] was used as a secondary standard to monitor accuracy and precision. Filtering and normalisation of analytical data followed the same protocols as those adopted for the LC21 and ODP967B tephra samples. EPMA sample analyses and accompanying standard analyses are provided in the supplementary information (Supplementary Material 1).

\subsection{Data Analysis}

The major element data determined by EPMA analysis was normalised to a volatile-free basis and presented on both bi-plots and a linear discriminant function analysis (DFA). Details of DFA are found in $[73,74]$, and it was undertaken using the PAST software of $[75,76]$. Data were converted to a log-ratio using the geometric mean of each analysis [74] and using $\mathrm{CaO}$ values as the root to avoid the unit sum problem of compositional data [73]. This dual approach to determining differences and similarities in the geochemistry between samples reflects that employed by [30].

\section{Results}

The results of the systematic counting of glass shard concentrations of LC21 and ODP967B tephras are provided in Figure 2, photomicrographs of each sample are shown in Figure 4, and plots of the measured major element ratios are provided in Figure 5. Here, we summarise the key findings to emerge from the data. All tephra samples are labelled according to their core name and lowermost (visible tephra layers) or mean sample depth (cryptotephra layers), e.g., the cryptotephra peak in core LC21 at 941-942 cm corresponds to sample "LC21 941.5". 

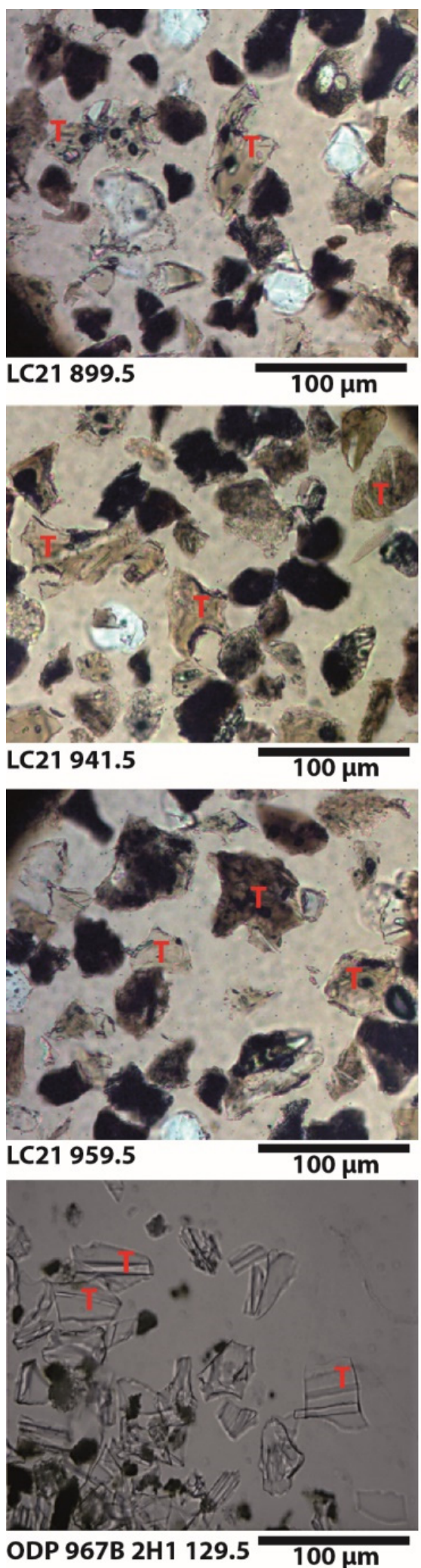
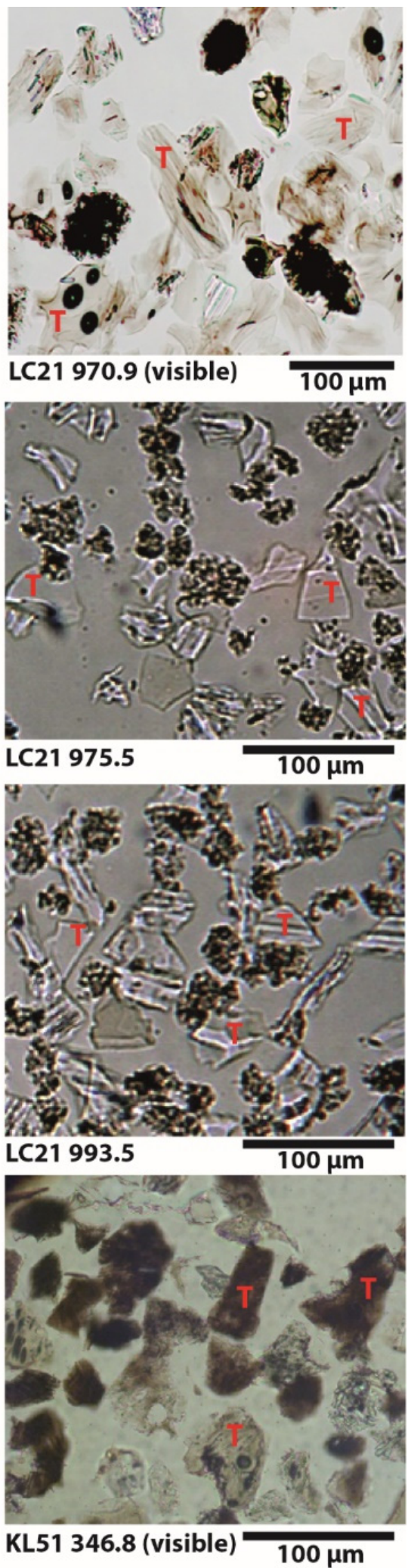

Figure 4. Photomicrographs (transmitted light) of the eight samples of tephra from cores LC21, KL51 and ODP967B. The labels "T" shows good examples of the tephra shards for each sample. See Figure 2 for the stratigraphic position of each sample. The slight blurring around the shards in LC21 975.5 and 993.5 is likely due to the age of the mounting medium in these samples. 

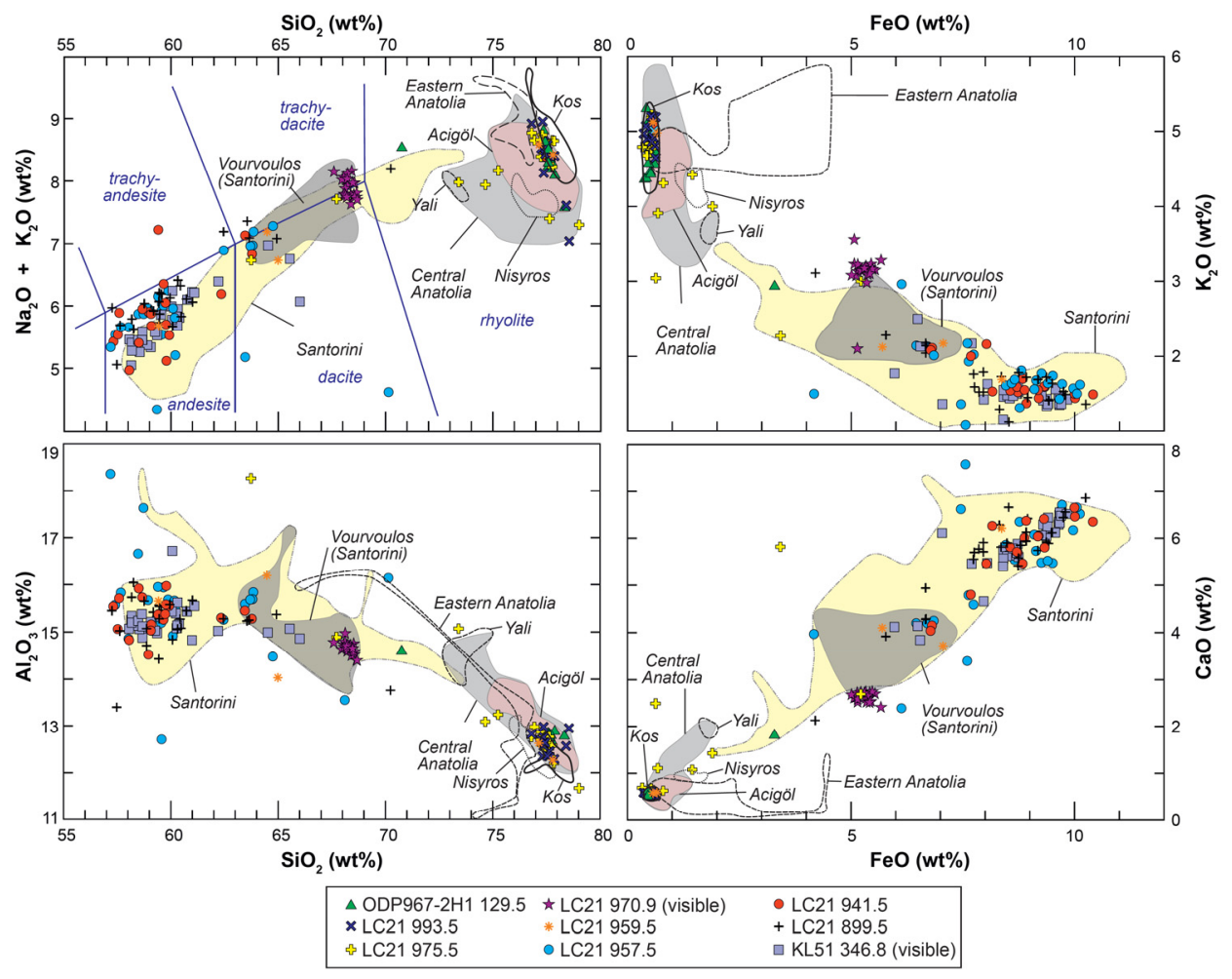

Figure 5. Top left: Total Alkali vs. Silica (TAS) diagram (after [77]) showing samples analysed in this study. Other panels show selected major element biplots of glass geochemistry from electron probe microanalysis (EPMA) of the tephra samples in this study. Reproducibility is $<10 \%$ relative standard deviation for analyses with concentrations $>0.8 \mathrm{wt} \%$ with the exception of $\mathrm{Na}_{2} \mathrm{O}(14 \%-15 \%)$. Full analytical results and standard analyses are provided in the supplementary data. Data for the LC21 970.9 (visible) tephra and LC21 957.5 are from [17]. Also shown are analyses of proximal tephras for comparison from: Santorini [48], Eastern Anatolia [78]; Central Anatolia including Acigöl [48,79]; Kos [17]; Nisyros [58]; Yali [13,14]. The geochemical field defined by proximal analyses of the Vourvoulos eruption of Santorini is shown separately from the rest of the Santorini field; see discussion in text.

\subsection{Geochemical Composition and Description of the ODP967B-2H1 129.5 Tephra}

Core ODP967B contains only one cryptotephra layer in the lower section of sapropel S5 at $129.5 \mathrm{~cm}$ depth in Section 2H1 (Figure 2) $(760.5 \mathrm{~cm}$ revised composite depth below sea floor). The shards are consistently colourless, platy and occasionally fluted in terms of morphology, and lack vesicles or mineral inclusions (Figure 4). Figures 5 and 6 show that the shards recovered from this layer (hereafter sample ODP967B-2H1 129.5) are geochemically homogeneous. Consistently high values for $\mathrm{SiO}_{2}$ $(\sim 77.5 \%)$ categorise this layer as high silica rhyolite (Figure 5$)$. Other geochemical features are that $\mathrm{K}_{2} \mathrm{O}$ values are significantly higher than those for $\mathrm{Na}_{2} \mathrm{O}$, while $\mathrm{CaO}$ values are only slightly higher than those for $\mathrm{FeO}^{\mathrm{t}}$ (Figure 5).

\section{Sedimentological Context of Tephra ODP967B-2H1 129.5}

The glass shard counts (Figure 2) show a well-defined discrete peak of cryptotephra ODP967B-2H1 129.5 in the core section. Such a tightly constrained ash layer suggests it to be a stratigraphically reliable indicator of a primary ash fall event, as reworked material would probably be spread vertically through a few centimetres of the core [11]. Furthermore, there is no indication of bioturbation in this section of the core, and previous studies of the ODP967B cores $[62,63,80]$ found no evidence of sediment reworking within the sapropel S5 sediment unit. 


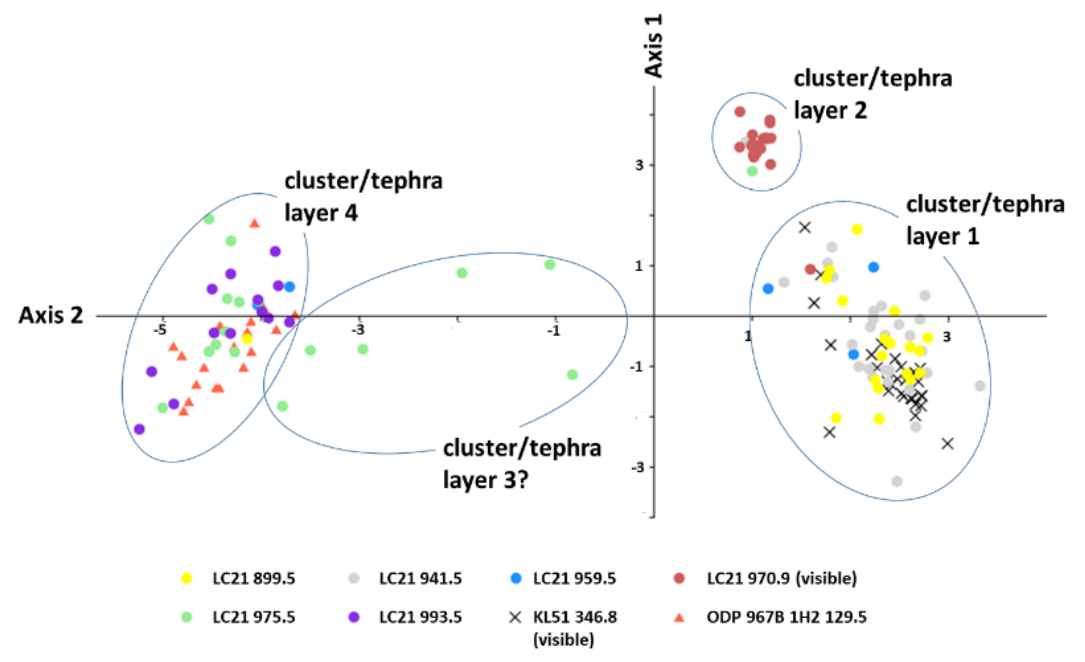

Figure 6. The 1st and 2nd canonical axes for linear discriminant function analysis (DFA) using EPMA major element data (Supplementary Materials 1 and 2) of all samples within marine cores LC21, KL51 and ODP967B-2H1. Data were converted to a log-ratio using the geometric mean of each analysis [74] and using $\mathrm{CaO}$ values as the root to avoid the unit sum problem of compositional data [73]. The DFA was completed using the PAST software of [75]. Four clusters of data imply separate eruption events/tephra layers. The question mark for tephra layer '3?' indicates a tentative definition of a discrete eruption event associated with the distinct peak in shard counts in sample LC21 975.5 (this sample also contains shards associated with cluster/tephra layers 2 and 4).

\subsection{Geochemical Composition and Description of LC21 Tephra Samples}

In addition to the already characterised tephra layer (LC21 970.9) in sapropel S5 [17], several new cryptotephra peaks have been detected (Figure 2). Notably, volcanic glass of variable concentrations was recorded continuously in the uppermost section of the S5 interval between 875.5 and $959.5 \mathrm{~cm}$ (Figure 2), from which three samples have been analysed.

\subsubsection{Cryptotephra LC21 993.5}

Shards in this cryptotephra sample are fluted and platy (Figure 4) and are rhyolitic in composition, with high normalised $\mathrm{SiO}_{2}$ values between $76.6 \mathrm{wt} \%$ and $78.5 \mathrm{wt} \%$ (Figure 5). $\mathrm{K}_{2} \mathrm{O}$ values of between $4.6 \mathrm{wt} \%$ and $5.2 \mathrm{wt} \%$ are always greater than $\mathrm{Na}_{2} \mathrm{O}$ values which vary between $2.1 \mathrm{wt} \%$ and $4.0 \mathrm{wt} \%$. $\mathrm{FeO}^{\mathrm{t}}$ is always $0.36-0.62 \mathrm{wt} \%$ and $\mathrm{CaO}$ concentrations vary between $0.51 \mathrm{wt} \%$ and $0.62 \mathrm{wt} \%$ (Figure 5).

\subsubsection{Cryptotephra LC21 975.5}

Shards recovered from this cryptotephra horizon are predominantly platy and light green or colourless (Figure 4). The EPMA data show the majority of shards to have a rhyolitic composition (Figure 5), though a small number have dacitic to trachydacitic affinities. These mixed chemical signatures result in a wide range of elemental concentrations (Figure 5), for example in FeO ${ }^{t}(0.4-5.0 w t \%)$ and $\mathrm{CaO}(0.5-5.7 \mathrm{wt} \%)$. On the other hand, values for $\mathrm{Na}_{2} \mathrm{O}(2.8-4.6 \mathrm{wt} \%)$ and $\mathrm{K}_{2} \mathrm{O}(2.2-4.7 \mathrm{wt} \%)$ are more homogeneous. A single shard in this layer forms a distinctive outlier, with a $\mathrm{SiO}_{2} \mathrm{value}$ of $65.1 \mathrm{wt} \%$ and $\mathrm{FeO}^{\mathrm{t}}$ concentration of $5.0 \mathrm{wt} \%$ (Figure 5).

\subsubsection{Visible Tephra LC21 970.9}

Tephra shards from this visible layer are generally clear to light brown in colour, platy or fluted with few vesicles or microcrystal inclusions (Figure 4). The EPMA data indicate a dacitic to trachydacitic composition (Figure 5) with $\mathrm{CaO}$ concentrations of 2.4-2.7 wt\%, always lower than the $\mathrm{FeO}^{\mathrm{t}}$ values of 5.0-5.7 wt\% (Figure 6). $\mathrm{Na}_{2} \mathrm{O}$ values (4.5-5.7 $\mathrm{wt} \%$ ) are consistently higher than those for $\mathrm{K}_{2} \mathrm{O}$ (2.10-3.56 wt\%; Figure 5). 


\subsubsection{Cryptotephras LC21 899.5, LC21 941.5 and LC21 959.5}

Shards from the cryptotephra peaks LC21 899.5, 941.5 and 959.5 from the uppermost tephra-rich interval exhibit a range of colours and morphologies but are dominated by blocky and vesicular brown shards with abundant mineral inclusions (Figure 4). The glass compositions of these cryptotephra samples are identical and suggest a wide chemical range from andesite to dacite (Figure 5). They are also identical to the compositions of a sample at $957.5 \mathrm{~cm}$ depth (from [17], shown also on Figure 5). $\mathrm{CaO}$ values (3.9-6.9 wt\%) are always lower than $\mathrm{FeO}^{\mathrm{t}}$ values (5.8-10.3 $\mathrm{wt} \%$ ) and $\mathrm{K}_{2} \mathrm{O}$ values are always less than $\mathrm{Na}_{2} \mathrm{O}$ values (Figure 5). Cryptotephra LC21 959.5 contains a mix of shards from the above described andesitic to dacitic composition and an additional high-silicic glass component $(n=2)$ that is comparable with the glass composition of tephra LC21 993.5 (Figure 5)

\subsubsection{Sedimentological Context of LC21 Tephra Samples}

The lowermost tephra sample LC21 993.5 was obtained from a distinct peak $(42,610$ shards per gram) in glass shard concentrations that lies close to the base of the sapropel S5 lithological unit (Figure 2) and has a homogenous chemical signature (Figure 5). Since this tephra sample is also confined within visible sediment laminations (see [21,54]) it is considered to represent an individual and primary eruption event.

Another cryptotephra peak was detected at $975.5 \mathrm{~cm}$ depth, $\sim 5 \mathrm{~cm}$ below the visible tephra layer. Yielding 18,722 shards per gram of sediment (Figure 2), this is a large increase over the samples below and above (3936 and 8417 shards per gram respectively) and thus could indicate input of primary air-fall tephra. Of 16 glass shards analysed for geochemical composition from this layer (Figure 5), one yielded a chemical signature similar to that of the overlying visible layer LC21 970.9 (Figures 5 and 6), and may, therefore, have been derived from it by localised redistribution through bioturbation of shards. Nine of the shards revealed compositional data that closely resemble those of the underlying sample LC21 993.5 (Figure 6), which might indicate reworking by the process described by [81]. The remaining 6 shards are geochemically distinct from all other samples in this study (Figures 5 and 6 ), and, therefore, may represent a primary tephra deposit. However, in view of the limited number of chemical measurements available, and the fact that reworked material appears to be the dominant component in this layer, this remains speculative, and in need of more rigorous investigation.

The $2 \mathrm{~mm}$-thick discrete tephra layer represented by sample LC21 970.9 (visible) (Figure 2) is interpreted as primary tephra fallout and described in more detail in [17].

Cryptotephra shards were found in all samples extracted from the upper part of the sapropel S5 unit in LC21 ranging between core depths 875.5 and $970.9 \mathrm{~cm}$, the latter depth marked by a visible tephra layer (Figure 2). This extensive spread of cryptotephra material (Figure 2) encompasses several peaks described in the previous section, and these are represented here by geochemical samples at core depths of $899.5 \mathrm{~cm}, 941.5 \mathrm{~cm}$, and $959.5 \mathrm{~cm}$ (and additionally $957.5 \mathrm{~cm}$ from [17], which all have near-identical chemical compositions (Figure 5). The sample at $959.5 \mathrm{~cm}$ depth also contains some (presumably reworked) glass shards from the lowermost rhyolitic tephra LC21 993.5 (Figure 5). There are three possible explanations for this tephra sequence:

(1) The tephra was continuously erupted and deposited throughout the period of time in which the upper part of Sapropel S5 was formed. However, linear interpolation between the dates for the top and the bottom of the sapropel (121.5 ka and $128.3 \mathrm{ka}$ respectively) in LC21 suggests a timespan of approximately 4000 to 5000 years for the period during which this spread of tephras was deposited; continuous eruption of geochemically homogeneous eruptive material over such a long time span seems highly unlikely.

(2) The spread reflects reworking by burrowing animals. Reworking on this scale seems unlikely, as sapropels are formed by anoxia of bottom waters, which would not support a thriving community of sea bottom burrowers. Furthermore, a detailed oxygen isotope stratigraphy for LC21 based on foraminifera [21,54] appears to be intact and coherent (i.e., it is not a "noisy" 
signal), while the sediments consist of undisturbed laminations and the visible tephra layer at $970.9 \mathrm{~cm}$ in the same core shows no upward or downward reworking [17] (Figure 2). However, some limited reworking by burrowing may have occurred as indicated by tephra sample LC21 959.5 which contains a mix of glass components from primary over- and underlying tephras.

(3) Prolonged deposition of tephra in the vicinity of LC21 could have been fed by reworked material removed from the trough slopes that surround the core site, in a similar manner to the process proposed by [81] which appears to generate "pseudo-isochrons" in deltaic sediments on a millennial timescale (see [81], Figure 5). In this process the reworked tephra shards (and other sediment grains) can be co-deposited with primary pelagic sediment for a long time after the eruption event.

Explanation 3 is considered the most likely here, as the process of the redeposition of tephra shards into an otherwise intact foraminiferal isotope stratigraphy has been observed in other sedimentary records [81] whereas the processes invoked by Explanations 1 and 2 have not been recognised elsewhere. Explanation 2 is also contradicted by the evidence in [21,54]. Unfortunately, however, it is still not possible to define the precise depth of this tephra layer in core LC21. The implications for the LC21 proxy stratigraphy of defining the eruption event at each of the depths sampled (899.5, 941.5 and 959.5 $\mathrm{cm}$ ) are provided in the supplementary information (Supplementary Information 4).

\subsection{Geochemical Composition and Description of the KL51 346.8 Tephra}

The visible tephra in core KL51 at 346.3-346.8 cm depth (hereafter sample KL51 346.8-Figure 3) consists of blocky, transparent to brownish-coloured glass shards (Figure 4) that are characterised by low to medium vesicularity and abundant mineral inclusions. The glass chemical composition of KL51 346.8 is rather heterogeneous, ranging from andesitic to dacitic (Figure 5) with $\mathrm{SiO}_{2}$ concentrations varying between $58.2 \mathrm{wt} \%$ and $66.2 \mathrm{wt} \%$. Figure 6 shows that $\mathrm{FeO}^{\mathrm{t}}$ and $\mathrm{CaO}$ values are highly variable at $6.0-9.7 \mathrm{wt} \%$ and 3.9-6.6 $\mathrm{wt} \%$, respectively, and $\mathrm{Na}_{2} \mathrm{O}(3.6-5.1 \mathrm{wt} \%)$ is greater in concentration than $\mathrm{K}_{2} \mathrm{O}(1.2-2.5 \mathrm{wt} \%)$.

\section{Sedimentological Context of Tephra Sample KL51 346.8}

The visible tephra layer KL51 346.8 is a visible dark layer (Figure 3) with slightly variable thickness due to bioturbation disturbance expressed as light-coloured burrows of submillimetric scale. As with other records from this area (see Figure 2 of [60]), this ash layer is found within the upper part of S5, about $4 \mathrm{~cm}$ below its upper boundary. Post-depositional Fucoides-type bioturbation (Figure 3) seems to compromise the sedimentary layering in the uppermost part of the sapropel S5 lithological unit; there is no sharp boundary, but rather a diffuse transition between organic rich sediments that become more and more mixed and obscured by strongly homogenized hemipelagic muds incorporated from above.

\section{Discussions}

In this section, we assess the possible correlations of the individual tephra deposits reported in Section 4 , and their potential to serve as regional isochrons. We do not attempt to definitively assign a detailed source to the tephra deposits, as a major constraint hampering this endeavour is the current paucity of relevant geochemical and geochronological information for the region's proximal volcanic strata of Eemian age, especially for nearby Aegean Arc and Anatolian volcanic provinces. For example, Santorini's proximal stratigraphy is well documented [82,83], but lacks glass chemical datasets for comparisons and precise radioisotopic dating of tephras $>100 \mathrm{ka}$. The volcanic stratigraphy of Kos, Yali and Nisyros is not well documented [84] or dated [85-87] for this time frame, and only few glass chemical data are available $[13,14,58,88]$. The eruptive history of the Central and Eastern Anatolian volcanoes is reasonably well established for the last 35 kyrs [48,78,89] and for $>160 \mathrm{ka}$ [79], but is lacking data for the Eemian time interval. Other potential but more distal sources include Italian volcanic provinces. A few less widespread tephra markers of Italian provenance and Eemian age 
have been reported from terrestrial sites in central and southern Italy [4,90], but those layers are all K-alkaline (trachytic-phonolitic) in composition and, therefore, unrelated to the silica saturated tephra layers presented here (see Figure 5). In the Adriatic Sea, [5] found shards in the middle of sapropel S5 preserved in core PRAD 1-2 (sample PRAD-3065), but unfortunately these were not able to be geochemically characterised, precluding a comparison to the data presented here. Therefore, in the absence of a robust regional proximal database, attempts to adduce the provenance of the tephra layers reported here will necessarily be preliminary in nature.

\subsection{Correlations Between Cores and Possible Sources of the Tephra}

Attempts to correlate the tephra deposits between the three cores described above used a two-stage approach: first, bi-plots of key elements were used to identify overlapping chemical ranges, then DFA (Figure 6) was employed to test for possible correlations. The first and second discriminant functions were plotted and any similarity visually inspected (Figure 6) in tandem with ad hoc utilisation of the stratigraphic positions of samples to identify any clear correlations between the tephra layers, and hence between the three sediment cores examined here (Figure 7, Table 1).
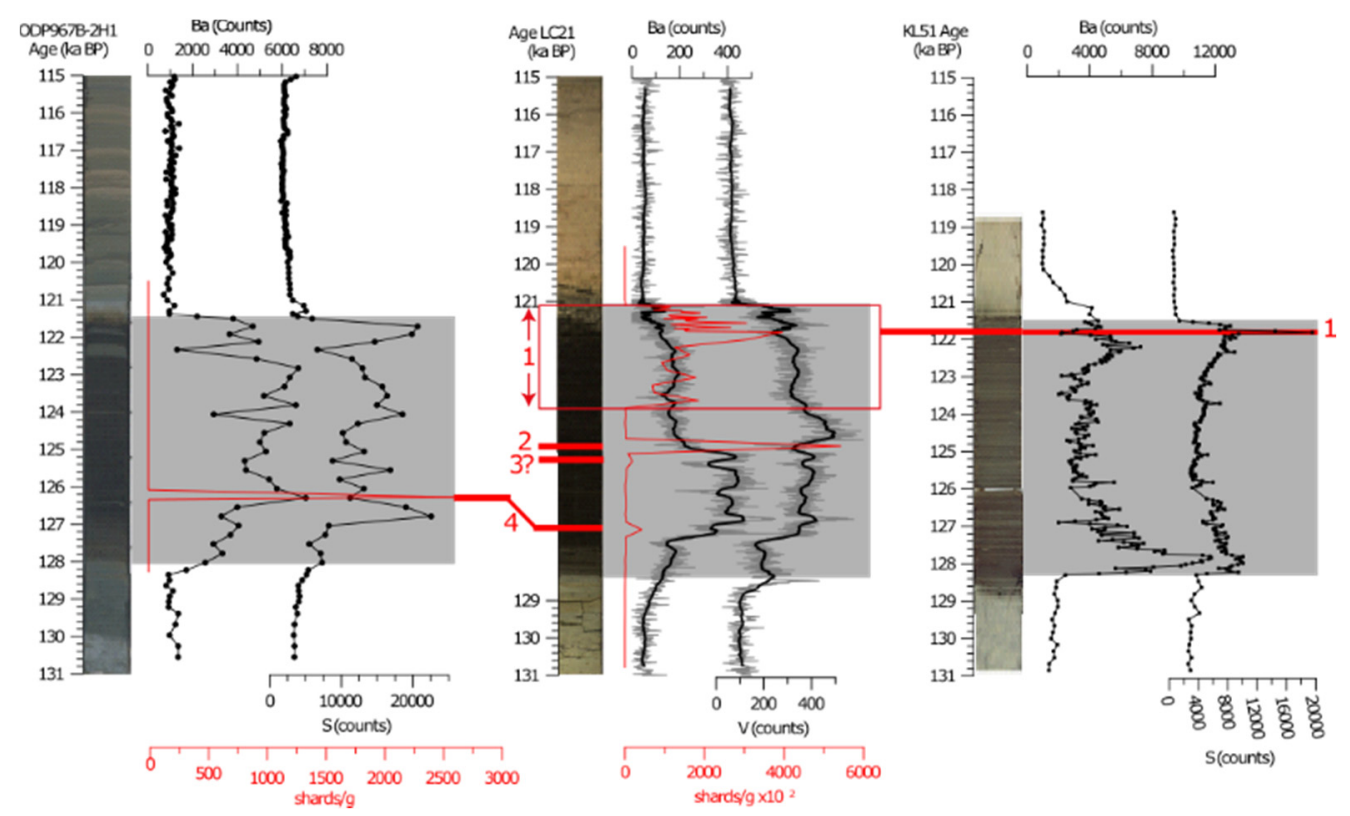

Figure 7. Chronology of sapropel S5 and tephra layers (red lines) in Eastern Mediterranean marine cores ODP967B-2H1, LC21, and KL51. All records as in Figure 2, but plotted against age instead of depth following the sapropel chronology of $[22,54]$. LC21 age scale within the sapropel is not shown, due to possible changes in the sedimentation rate in this core; see text for discussion. Numbered red lines $(1,2,3$ ? and 4$)$ indicate proposed tephra layer based on the major element glass chemistry and relate to the numbers of the data clusters defined by the DFA (Figure 6). Tephra 1 in LC21 is shown over a range of depths (red box) reflecting the depth uncertainty of the correlation with KL51 346.8; the analyses of all tephra samples within this red box in LC21 $(899.5,941.5$ and $959.5 \mathrm{~cm})$ are indistinguishable from one another. Tephra layer 2 is represented by sample LC21 970.9 (visible), tephra layer 3? is a possible eruption event represented by sample LC21 975.5 and tephra layer 4 is represented by samples ODP967B-2H1 129.5 and LC21 993.5. Shard, Ba and V counts in LC21 have been aligned to the KL51 core on the cautious interpretation that sample LC21 941.5 is synchronous with the KL51 346.8 (visible) tephra; see supplementary information for discussion. 
Table 1. Summary of correlations, interpolated ages and suggested sources of tephra layers in Mediterranean Sapropel S5. Ages are derived from linear interpolation between the ages for the top (121.5 ka) and base (128.3 ka) of S5 [54].

\begin{tabular}{|c|c|c|c|c|c|}
\hline $\begin{array}{l}\text { Samples Comprising } \\
\text { Tephra Layer (Figure 7) }\end{array}$ & $\begin{array}{l}\text { Tephra Layer Number } \\
\text { (Figures } 6 \text { and } 7 \text { ) }\end{array}$ & $\begin{array}{l}\text { TAS Classification of } \\
\text { Tephra Layer (Figure 5) }\end{array}$ & $\begin{array}{l}\text { Interpolated } \\
\text { Age of Tephra } \\
\text { Layer }\end{array}$ & Method of Age Interpolation & $\begin{array}{l}\text { Suggested } \\
\text { Sources for } \\
\text { Tephra Layer } \\
\text { (from Figure 5) }\end{array}$ \\
\hline LC21 970.9 (visible) & 1 & Dacitic to trachytic & $\begin{array}{l}>121.8 \pm 2 \mathrm{ka} \\
<126.4 \pm 2 \mathrm{ka}\end{array}$ & $\begin{array}{c}\text { Youngest age constrained by KL51 } \\
346.8 \text { (visible). Oldest age } \\
\text { constrained by ODP967B } \\
2 \mathrm{H} 1129.5\end{array}$ & $\begin{array}{l}\text { Santorini } \\
\text { (Vourvoulos } \\
\text { eruption) }\end{array}$ \\
\hline LC21 975.5 & $3 ?$ & Rhyolitic & $\begin{array}{l}>121.8 \pm 2 \mathrm{ka} \\
<126.4 \pm 2 \mathrm{ka}\end{array}$ & $\begin{array}{c}\text { Youngest age constrained by KL51 } \\
346.8 \text { (visible). Oldest age } \\
\text { constrained by ODP967B } \\
2 \mathrm{H} 1129.5\end{array}$ & $\begin{array}{c}\text { Santorini, } \\
\text { Kos/Yali/Nisyros, } \\
\text { Central/Eastern } \\
\quad \text { Anatolia } \\
\end{array}$ \\
\hline $\begin{array}{c}\text { LC21 } 993.5 \text { and } \\
\text { ODP967B 2H1 129.5 }\end{array}$ & 4 & Rhyolitic & $>126.4 \pm 2 \mathrm{ka}$ & $\begin{array}{c}\text { Linear Interpolation between top } \\
\text { (121.5 ka) and base (128.3 ka) of S5 } \\
\text { in core ODP967B 2H1 }\end{array}$ & $\begin{array}{l}\text { Kos/Yali/Nisyros, } \\
\text { Central/Eastern } \\
\text { Anatolia }\end{array}$ \\
\hline
\end{tabular}

The oldest tephra deposits reported here are those lying close to the lower boundary of the S5 sediment units in ODP967B and LC21 (Figure 2). Layers ODP967B-2H1 129.5 and LC21 993.5 cannot be differentiated either through their major element concentrations (Figure 5) or the DFA plot (Figure 6). Given their indistinguishable high-silica rhyolitic chemical compositions and similar stratigraphic position, it is reasonable to interpret that they represent the same eruption event, and hence provide a proxy-independent isochron for linking Eemian and S5 records between the Aegean and Levantine seas (Figures 1, 7 and 8$)$. The high $\mathrm{SiO}_{2}$ content $(\sim 77 \mathrm{wt} \%)$ and very low $\mathrm{CaO}$ and $\mathrm{FeO}$ concentrations of these rhyolitic shards indicate a likely origin from either Central Anatolia volcanoes (e.g., Acigöl) or from the Kos-Nisyros-Yali volcanic system (SE Aegean Arc) (Figures 1 and 5).

Sample LC21 975.5 represents a cryptotephra peak $18 \mathrm{~cm}$ above the basal LC21 993.5 layer and only $5 \mathrm{~cm}$ below the visible tephra layer LC21 970.9 (Figure 2). As noted in Section 4, this sample yields shards with similar compositions to samples LC21 993.5 (below) and LC21 970.9 (above) (Figure 6), possibly indicating reworking of these tephra shards through bioturbation or redeposition. It does, however, also include rhyolitic shards $(n=6)$ which are chemically distinct from those of all other layers analysed within this study (tephra layer 3? in the DFA, where the question mark indicates uncertainty, see Figure 6). These could signal an additional distinctive eruption event associated with sapropel S5. Alternatively, the analyses obtained from this sample, considered together, could simply represent geochemical variation within one eruption. Here, we tentatively propose a tephra layer on the basis of a sharp peak in shard concentrations, but caution that these results would need to be replicated in other sediment sequences from the region for this interpretation to be confirmed. The rhyolitic shards show some affinities to Central and Eastern Anatolian tephras (Figure 5).

Just above the samples described above (see Figure 2) is the $\sim 2 \mathrm{~mm}$ thick visible layer LC21 970.9, first reported in [17] with a glass composition that does not match any of the other samples presented here (Figures 5 and 6). It, therefore, represents a distinctive eruption event. Being dacitic to trachydacitic in glass composition (Figure 5), it conforms to the geochemical ranges of proximal deposits on Santorini [17] and is outside the chemical range of other nearby Aegean Volcanic Arc sources (Nisyros, Yali, Kos), as well as of Anatolian or Italian volcanoes [17]. Glass chemical data available for Santorini proximal tephras is limited to only a few major eruptions from the time intervals $<100 \mathrm{ka}$ [48] and $>200 \mathrm{ka}$ [33], hence still hampering detailed correlations. Several of the Plinian events evident in the proximal stratigraphy of Santorini are undated. However, the similarly dacitic-trachydacitic Vourvoulos eruption is currently constrained to between $\sim 152$ and $\sim 47$ ka by the dates of the underlying (Middle Pumice) and overlying (Upper Scoria 2) deposits and is thus a viable candidate eruption for this Eemian tephra layer. Figure 5 shows that the EPMA of LC21 970.9 (visible) matches the 
composition of the silicic end-member of the Vourvoulos proximal deposits [57] and we propose an attribution to this eruption.

The youngest discrete tephra layer reported here is the KL51 346.8 tephra. It is a visible layer occurring close to the upper boundary of the S5 sediment unit (Figure 3). Both the major element bi-plots (Figure 5) and DFA plot (Figure 6), where these shards together form cluster 1, indicate that the glass chemistries of these samples are indistinguishable from (and, therefore, correlate to) the uppermost three tephra samples from core LC21, namely LC21 899.5, 941.5, and 959.5. A sample at $957.5 \mathrm{~cm}$ depth (from [17]) also matches this composition (Figure 5). The three LC21 samples represent tephra peaks selected for analysis from a series of tephra samples that extend continuously over a $>70 \mathrm{~cm}$ sediment interval (Figure 2) with LC21 959.5 being the basal sample. As previously discussed, the thick sequence of tephra peaks in the upper part of S5 in core LC21 (Figure 2) results most probably from prolonged redeposition of tephra from the slopes surrounding the sedimentary basin, rather than in-situ reworking (for example by bioturbation). This interpretation is supported by the observation of undisturbed laminations in S5 in LC21 [54]. A range of possible correlations between the KL51 346.8 tephra and the LC21 shard count peaks presented in this paper are discussed in the supplementary information (Supplementary Material 4) with respect to the known biostratigraphy of the core. However, as no precise correlation can be made between the cores at present, these results highlight the need for trace element analyses of the tephra layers $[17,58]$.

If differences in concentrations of fractionation-sensitive trace elements such as Ba or Sr can be detected between otherwise geochemically identical samples within the same core (such as LC21 899.5, 941.5 and $959.5 \mathrm{~cm}$ ), this would support an interpretation that each peak in shard concentrations represents a separate eruption event. In addition, trace element analyses could also assist in the attribution of volcanic source regions to the tephra layers. For example, $\mathrm{Rb}, \mathrm{Nb}, \mathrm{Ta}, \mathrm{Y}$ and $\mathrm{Th}$ are proposed to good discriminators between active and post-subduction tectonic settings [48] and so could discriminate between the Aegean Arc (active) and Anatolian (post-subduction) sources proposed here for tephra samples LC21 $993.5 \mathrm{~cm}$ and ODP967B 2H1 $129.5 \mathrm{~cm}$.

Notwithstanding the difficulty in determining the precise correlation between LC21 and KL51, the andesitic to dacitic composition of these tephras strongly suggests an origin from an eruption of the Santorini volcano (Figure 5), which is known to have produced such compositions at least within the last 100 kyrs [48].

\subsection{Age Estimates of the Tephra Deposits}

Ideally, to maximise their utility, the ages of tephra layers should be derived by direct or indirect radiometric measurements from sequences with well-understood sedimentary contexts. However, the increasing numbers of detected tephra layers that are only registered at distal locations means this is not always possible, as these layers usually do not have sufficient material to obtain absolute age estimates in this manner. Hence, the inferred ages of such tephra layers are usually reliant on the robustness of age models based on independent evidence [4].

The tephra layers reported in this study have not been dated directly, so the ages presented here (Table 1) are derived from linear interpolation between age estimates with $2 \sigma$ uncertainty previously established for the upper (121.5 $\pm 2 \mathrm{ka})$ and lower (128.3 $\pm 2 \mathrm{ka})$ boundaries of sapropel S5 in Eastern Mediterranean sediments [21]. These sapropel ages themselves are derived from an age model developed for the LC21 core sequence by [54]. Briefly, this is based on radiocarbon dates and two well-dated tephra layers (the Minoan and Campanian Ignimbrite eruption events) for the $0-40 \mathrm{ka}$ interval, and constrained by tuning the LC21 planktonic foraminiferal $\delta^{18} \mathrm{O}$ record to the U/Th-dated Soreq Cave (Israel) speleothem $\delta^{18} \mathrm{O}$ record [91] for the 40-150 ka interval. Robust tie points link the top and base of sapropel S5 in LC21 to Soreq $\delta^{18} \mathrm{O}$ record, but crucially no intermediate tie points were proposed [54]. Hence the tephra age estimates provided here were necessarily derived by linear interpolation between the top and base of S5. They should, therefore, be regarded as provisional, because their derivation rests on the assumed correspondence of stratigraphic markers (the top and 
bottom of sapropel S5) between deep sea-floor pelagic sediments of cores ODP967B-2H1, LC21 and KL51, and between changes in the $\delta^{18} \mathrm{O}$ of eastern Mediterranean surface waters and Soreq cave speleothems. The latter relationship derives from a shared physical mechanism whereby evaporation from the eastern Mediterranean Sea provides the dominant source of precipitation over Soreq Cave (hence, the $\delta^{18} \mathrm{O}$ "source" signal is preserved in Soreq speleothems) [54,91]. Although there is thought to be a lag time of up to 400-600 years between deposition of S5 in the west and east of the Eastern Mediterranean basin [55], this is much smaller than the $2 \sigma$ uncertainty of ages defined for the top $(121.5 \pm 2 \mathrm{ka})$ and base $(128.3 \pm 2 \mathrm{ka})$ of sapropel S5. Any asynchronicity between cores is, therefore, accommodated by the uncertainties of these dates. Defining age estimates for the tephra layers here does not preclude their valuable use as proxy-independent isochrones. It also allows them to provide a unique chronological contribution to the eruptive history of the region.

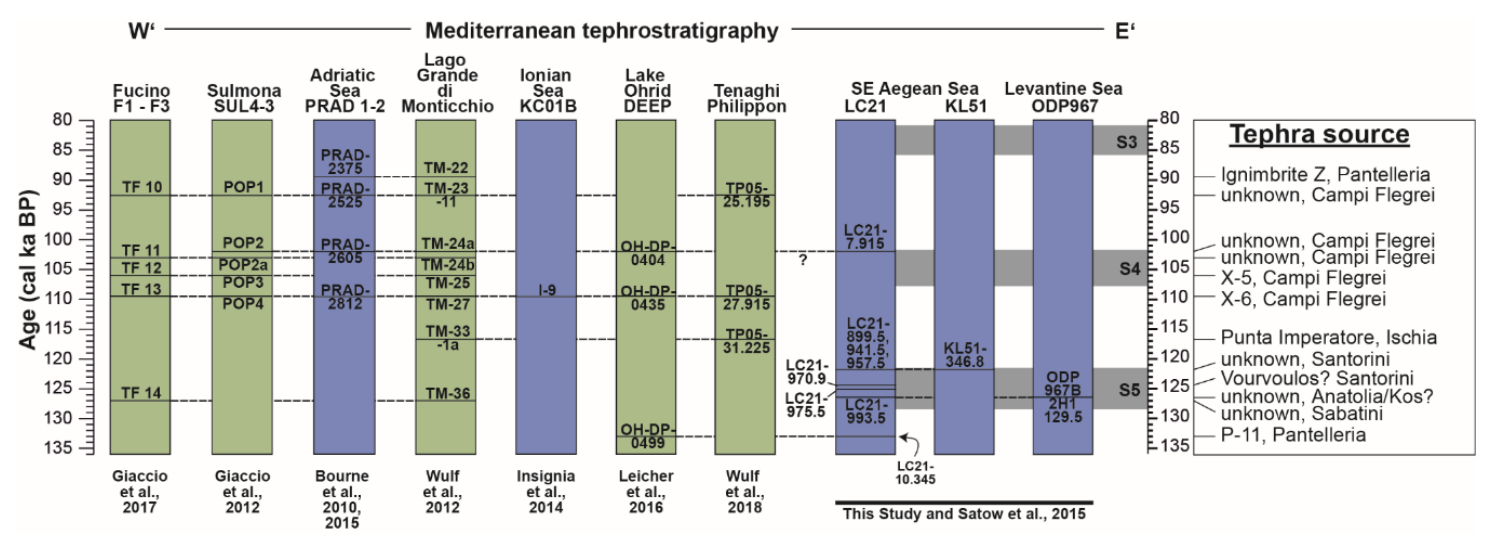

Figure 8. Tephrostratigraphic correlations of MIS 5 terrestrial and marine sediments in the Eastern Mediterranean region. See Figure 1 for position of sites. Core and tephra data derive from: Fucino palaeolake, central Italy [90]; Sulmona palaeolake, central Italy [92]; PRAD 1-2, central Adriatic Sea [5,30]; Lago Grande di Monticchio, southern Italy [4]; KC01B, Ionian Sea [46]; Lake Ohrid, Albany/Macedonia [93]; Tenaghi Philippon, northeastern Greece [32]; LC21, KL51 and ODP967B (this study). Positions of sapropels S3-S5 are included for comparison.

The age of $121.8 \pm 2 \mathrm{ka}(2 \sigma$ uncertainty; Table 1$)$ for the upper tephra marker KL51 346.8 (corresponding to samples LC21 959.5, 941.5 and 899.5) is derived from linear interpolation in core KL51 between the ages of the start and end of sapropel S5, as outlined above. The age estimate for the oldest tephra marker ODP967B-2H1 129.5 (corresponding to LC21 993.5) at $126.4 \pm 2 \mathrm{ka}$ is derived by linear interpolation in core ODP967B-2H1 between the ages of the start and the end of sapropel S5 (Table 1).

Bracketed between these two tephra deposits, but only represented in core LC21, are two further tephra layers, LC21 970.9 (visible) and LC21 975.5 (clusters/tephra layers 2 and 3? in Figure 7). Due to the uncertainty in the correlation of the tephra in the uppermost part of S5 in LC21 with the KL51 core (layer 1, Figure 7), their ages can only be constrained stratigraphically by being older than the KL51 346.8 tephra (121.8 $\pm 2 \mathrm{ka}$ ) and younger than the ODP967B-2H1 129.5 tephra at $126.4 \pm 2 \mathrm{ka}$. Table 1 summarises these stratigraphical and chronological interpretations.

\subsection{Synthesis with the Regional Tephrostratigraphy}

The four tephra layers described here are the first to be characterised within the Eemian, Eastern Mediterranean sapropel S5 and significantly add to the known tephrostratigraphy in this region (Figure 8). These Eemian sediments preserve a valuable record of the climate of the last interglacial period. Furthermore, volcanic stratigraphies in the region are often poorly dated $[82,87]$ and so this updated regional tephrostratigraphy (Figure 8) has both palaeoenvironmental and volcanological applications. Prior to this publication, Eemian tephra layers in the Mediterranean have only been 
characterised in terrestrial sites in central and southern Italy, namely in Fucino [90] and Lago Grande di Monticchio [4]. Unfortunately, those are layers of Italian provenance and do not allow correlation to the marine sequences described here (Figure 8). However, other older and younger tephras such as the Pantelleria P-11 tephra (133 ka) and possibly the Campanian POP2/TM-24a tephra (102 ka) [92] are valuable markers which may prove invaluable in the precise synchronisation of terrestrial and marine records throughout the Mediterranean (Figure 8). In many cases, these tephra layers also provide the only chronological constraints for volcanic stratigraphies. For example, here, we suggest a date range for the Vourvoulos eruption of Santorini (Figure 8, Table 1).

\section{Conclusions}

Four Eemian tephra layers have been geochemically characterised using samples from three marine sediment cores spanning the Aegean and Levantine Seas. These tephra layers open new opportunities to correlate the proxy records of these cores with terrestrial or other marine environmental records in the region, as well as with archaeological sites. The assignation of provisional dates to these horizons in this paper also provides an opportunity for them to improve regional volcanic chronologies-many of which are currently poorly constrained. EPMA data indicate that a distinctive high-silica rhyolitic tephra of either Kos or Anatolian origin, dated by interpolation to approximately $126.4 \pm 2 \mathrm{ka}$, links the S5 sediments of the SE Aegean Sea (core LC21) with those of the Levantine Basin (core ODP967) in a ca. $600 \mathrm{~km}$ West-East transect. An andesitic-dacitic tephra of likely Santorini provenance and an age of $121.8 \pm 2$ ka links the uppermost S5 sediments of the two southern Aegean records (KL51 and LC21), representing a more localised tephra marker in this region. The other two tephra layers; one dacitic-trachydacitic, the other rhyolitic, are proposed to originate from Santorini (the Vourvoulos eruption) and Central or Eastern Anatolian volcanic activity respectively. Their ages can be constrained to between $121.8 \pm 2 \mathrm{ka}$ and $126.4 \pm 2 \mathrm{ka}$. These have only been detected in core LC21 thus far, but their potential to serve as regional isochrons in the southern Aegean Sea merits further exploration.

Supplementary Materials: The following are available online at http://www.mdpi.com/2571-550X/3/1/6/s1. All major element tephra analyses of the tephra layers and standard data are provided in Supplementary Material 1. Supplementary Material 2 contains the major element analyses of sample LC21 970.9 (from [17]). Details of the XRF scanning procedures for core KL51 (not previously published) are provided in Supplementary Material 3. Supplementary Material 4 is a discussion of possible tephra correlations between cores LC21 and KL51. Reference [94] is cited in Supplementary Material 4.

Author Contributions: All authors contributed with text writing. Figures 1, 5 and 8 were produced by S.W., Figures 2, 4 and 7 by C.S., Figure 3 by H.S., and Figure 6 by A.M. and I.M. Additionally, C.S., I.M. and A.M. obtained tephra glass chemical data from cores LC21 and ODP967. K.G. provided scanning XRF and age model data for LC21 and ODP967, the chronological data and co-produced Figures 2 and 7. S.W. contributed with tephra glass chemical data from core KL51. H.S. coordinated sampling of KL51 for XRF-scanning in Bremen. All authors have read and agree to the published version of the manuscript.

Funding: K.G. is funded by the Australian Research Council, Grant Number DE1900100042. Work on core LC21 by C.S., A.M. and I.M. was funded by Natural Environment Research Council Grant Number NE/E015905/1.

Acknowledgments: Access to core M40-4 KL51 has been provided by the GeoB Core Repository at MARUM and this research also used data acquired at the XRF Core Scanner Lab at the MARUM-Center for Marine Environmental Sciences, University of Bremen, Germany. Vera Bender, Vera Lukies and Ursula Röhl are thanked for their assistance at MARUM. Wilma Rehder (Kiel) produced the high-quality radiographies of core M40/4 SL67. Karen Fontijn at the University of Oxford is thanked for her assistance producing the tephra EPMA data for cores LC21 and ODP967B-2H1, and Oona Appelt at the GFZ Potsdam for helping during tephra EPMA analysis on core KL51. Materials are stored at MARUM Bremen, Tübingen University, BOSCORF (Southampton, UK) and Portsmouth University. Steffen Kutterolf and another anonymous reviewer are thanked for their careful reviews of this manuscript. Their astute comments and suggestions have greatly improved the paper.

Conflicts of Interest: The authors declare no conflict of interest. The funders had no role in the design of the study; in the collection, analyses, or interpretation of data; in the writing of the manuscript, or in the decision to publish the results 


\section{References}

1. Lowe, J.; Barton, N.; Blockley, S.; Ramsey, C.B.; Cullen, V.; Davies, W.; Gamble, C.; Grant, K.; Hardiman, M.; Housley, R.; et al. Volcanic Ash layers illuminate the resilience of Neanderthals and early modern humans to natural hazards. Proc. Natl. Acad. Sci. USA 2012, 34, 13532-13537. [CrossRef]

2. Lane, C.S.; Brauer, A.; Blockley, S.P.E.; Dulski, P. Volcanic ash reveals time-transgressive abrupt climate change during the Younger Dryas. Geology 2013, 41, 1251-1254. [CrossRef]

3. Lane, C.S.; Lowe, D.J.; Blockley, S.P.E.; Suzuki, T.; Smith, V.C. Advancing tephrochronology as a global dating tool: Applications in volcanology, archaeology, and palaeoclimatology. Quat. Geochronol. 2017, 40, 1-7. [CrossRef]

4. Wulf, S.; Keller, J.; Paterne, M.; Mingram, J.; Lauterbach, S.; Opitz, S.; Sottili, G.; Giaccio, B.; Albert, P.G.; Satow, C.; et al. The 100-133 ka record of Italian explosive volcanism and revised tephrochronology of Lago Grande di Monticchio. Quat. Sci. Rev. 2012, 58, 104-123. [CrossRef]

5. Bourne, A.J.; Albert, P.G.; Matthews, I.P.; Trincardi, F.; Wulf, S.; Asioli, A.; Blockley, S.P.E.; Keller, J.; Lowe, J.J. Tephrochronology of core PRAD 1-2 from the Adriatic Sea: Insights into Italian explosive volcanism for the period 200-80ka. Quat. Sci. Rev. 2015, 116, 28-43. [CrossRef]

6. Matthews, I.P.; Trincardi, F.; Lowe, J.J.; Bourne, A.J.; MacLeod, A.; Abbott, P.M.; Andersen, N.; Asioli, A.; Blockley, S.P.E.; Lane, C.S.; et al. Developing a robust tephrochronological framework for Late Quaternary marine records in the Southern Adriatic Sea: New data from core station SA03-11. Quat. Sci. Rev. 2015, 118, 84-104. [CrossRef]

7. Allan, A.S.R.; Baker, J.A.; Carter, L.; Wysoczanksi, R.J. Reconstructing the Quaternary evolution of the world's most active silicic volcanic system: Insights from an $\sim 1.65$ Ma deep ocean tephra record sourced from Taupo Volcanic Zone, New Zealand. Quat. Sci. Rev. 2008, 27, 2341-2360. [CrossRef]

8. Paterne, M.; Guichard, F.; Duplessy, J.C.; Siani, G.; Sulpizio, R.; Labeyrie, J. A 90,000-200,000 yrs marine tephra record of Italian volcanic activity in the central Mediterranean Sea. J. Volcanol. Geoth. Res. 2008, 177, 187-196. [CrossRef]

9. Lane, C.S.; Andric, M.; Cullen, V.; Blockley, S. The occurrence of distal Icelandic and Italian tephra in the Lateglacial of Lake Bled, Slovenia. Quat. Sci. Rev. 2011, 30, 1013-1018. [CrossRef]

10. Albert, P.G.; Tomlinson, E.L.; Smith, V.C.; Di Roberto, A.; Todman, A.; Rosi, M.; Marani, M.; Müller, W.; Menzies, M.A. Marine-continental tephra correlations: Volcanic glass geochemistry from the Marsili Basin and the Aeolian Islands, South Tyrrhenian Sea, Italy. J. Volcanol. Geoth. Res. 2012, 229, 74-94. [CrossRef]

11. Wall-Palmer, D.; Coussens, M.; Talling, P.J.; Jutzeler, M.; Cassidy, M.; Marchant, I.; Palmer, M.R.; Watt, S.F.L.; Smart, C.W.; Fisher, J.K.; et al. Late Pleistocene stratigraphy of IODP Site U1396 and compiled chronology offshore of south and south west Montserrat, Lesser Antilles. Geochem. Geophys. Geosyst. 2014, 15, 3000-3020. [CrossRef]

12. Fontijn, K.; Rawson, H.; Van Daele, M.; Moernaut, J.; Abarzúa, A.M.; Heirman, K.; Bertrand, S.; Pyle, D.M.; Mather, T.A.; De Batist, M.; et al. Synchronisation of sedimentary records using tephra: A postglacial tephrochronological model for the Chilean Lake District. Quat. Sci. Rev. 2016, 137, 234-254. [CrossRef]

13. Federman, A.N.; Carey, S.N. Electron Microprobe correlation of tephra layers from Eastern Mediterranean. Quat. Res. 1980, 13, 160-171. [CrossRef]

14. Vinci, A. Distribution and chemical composition of Tephra layers from the Eastern Mediterranean abyssal sediments. Mar. Geol. 1985, 64, 143-155. [CrossRef]

15. Aksu, A.E.; Jenner, G.; Hiscott, R.N.; Isler, E.B. Occurrence, stratigraphy and geochemistry of late Quaternary tephra layers in the Aegean Sea and Marmara Sea. Mar. Geol. 2008, 252, 174-192. [CrossRef]

16. Çağatay, M.N.; Wulf, S.; Sancar, Ü.; Özmaral, A.; Vidal, L.; Henry, P.; Appelt, O.; Gasperini, L. The tephra record from the Sea of Marmara for the last ca. $70 \mathrm{ka}$ and its palaeoceanographic implications. Mar. Geol. 2015, 361, 96-110. [CrossRef]

17. Satow, C.; Tomlinson, E.L.; Grant, K.M.; Albert, P.G.; Smith, V.C.; Manning, C.J.; Ottolini, L.; Wulf, S.; Rohling, E.J.; Lowe, J.J.; et al. A new contribution to the Late Quaternary tephrostratigraphy of the Mediterranean: Aegean Sea core LC21. Quat. Sci. Rev. 2015, 117, 96-112. [CrossRef]

18. Rohling, E.J.; Marino, G.; Grant, K.M. Mediterranean climate and oceanography, and the periodic development of anoxic events (sapropels). Earth-Sci. Rev. 2015, 143, 62-97. [CrossRef]

19. Revel, M.; Ducassou, E.; Grousset, F.E.; Bernasconi, S.M.; Migeon, S.; Revillon, S.; Mascle, J.; Murat, A.; Zaragosi, S.; Bosch, D. 100,000 years of African monsoon variability recorded in sediments of the Nile margin. Quat. Sci. Rev. 2010, 29, 1342-1362. [CrossRef] 
20. Ziegler, M.; Tuenter, E.; Lourens, L.J. The precession phase of the boreal summer monsoon as viewed from the eastern Mediterranean (ODP Site 968). Quat. Sci. Rev. 2010, 29, 1481-1490. [CrossRef]

21. Grant, K.M.; Grimm, R.; Mikolajewicz, U.; Marino, G.; Ziegler, M.; Rohling, E.J. The timing of Mediterranean sapropel deposition relative to insolation, sea-level and African monsoon changes. Quat. Sci. Rev. 2016, 140, 125-141. [CrossRef]

22. Grant, K.M.; Rohling, E.J.; Westerhold, T.; Zabel, M.; Heslop, D.; Konijnendijk, T.; Lourens, L.J. A 3 million year index for North African humidity/aridity and the implication of potential pan-African Humid Periods. Quat. Sci. Rev. 2017, 171, 100-118. [CrossRef]

23. Rohling, E.; Mayewski, P.; Abu-Zied, R.; Casford, J.; Hayes, A. Holocene atmosphere-ocean interactions: Records from Greenland and the Aegean Sea. Clim. Dynam. 2002, 18, 587-593.

24. Casford, J.S.L.; Rohling, E.J.; Abu-Zied, R.H.; Fontanier, C.; Jorissen, F.J.; Leng, M.J.; Schmiedl, G.; Thomson, J. A dynamic concept for eastern Mediterranean circulation and oxygenation during sapropel formation. Palaeogeogr. Palaeoclimatol. Palaeoecol. 2003, 190, 103-119. [CrossRef]

25. Van der Meer, M.T.J.; Baas, M.; Rijpstra, W.I.C.; Marino, G.; Rohling, E.J.; Sinninghe Damsteé, J.S.; Schouten, S. Hydrogen isotopic compositions of long-chain alkenones record freshwater flooding of the Eastern Mediterranean at the onset of sapropel deposition. Earth Planet. Sci. Lett. 2007, 262, 594-600. [CrossRef]

26. Marino, G.; Rohling, E.J.; Rijpstra, W.I.C.; Sangiorgi, F.; Schouten, S.; Sinninghe Damsteé, J.S. Aegean Sea as driver of hydrographic and ecological changes in the eastern Mediterranean. Geol. Soc. Am. 2007, 35, 675-678. [CrossRef]

27. Marino, G.; Rohling, E.J.; Sangiorgi, F.; Hayes, A.; Casford, J.L.; Lotter, A.F.; Kucera, H.; Brinkhuis, H. Early and middle Holocene in the Aegean Sea: Interplay between high and low latitude climate variability. Quat. Sci. Rev. 2009, 28, 3246-3262. [CrossRef]

28. Siani, G.; Magny, M.; Paterne, M.; Debret, M.; Fontugne, M. Paleohydrology reconstruction and Holocene climate variability in the South Adriatic Sea. Clim. Past 2013, 9, 499-515. [CrossRef]

29. Gogou, A.; Triantaphyllou, M.; Xoplaki, E.; Izdebski, A.; Parinos, C.; Dimiza, M.; Bouloubassi, I.; Luterbacher, J.; Kouli, K.; Martrat, B.; et al. Climate variability and socio-environmental changes in the northern Aegean (NE Mediterranean) during the last 1500 years. Quat. Sci. Rev. 2016, 136, 209-228. [CrossRef]

30. Bourne, A.; Lowe, J.J.; Trincardi, F.; Asioli, A.; Blockley, S.P.E.; Wulf, S.; Matthews, I.P.; Piva, A.; Vigliotti, L. Distal tephra record for the last ca 105,000 years from core PRAD 1-2 in the central Adriatic Sea: Implications for marine tephrostratigraphy. Quat. Sci. Rev. 2010, 29, 3079-3094. [CrossRef]

31. Damaschke, M.; Sulpizio, R.; Zanchetta, G.; Wagner, B.; Böhm, A.; Nowaczyk, N.R.; Rethemeyer, J.; Hilgers, A. Tephrostratigraphic studies on a sediment core from Lake Prespa in the Balkans. Clim. Past 2013, 9, 267-287. [CrossRef]

32. Wulf, S.; Hardiman, M.; Staff, R.A.; Koutsodendris, A.; Appelt, O.; Blockley, S.P.E.; Lowe, J.J.; Manning, C.J.; Ottolini, L.; Schmitt, A.K.; et al. The marine isotope stage 1-5 cryptotephra record of Tenaghi Philippon, Greece: Towards a detailed tephrostratigraphic framework for the Eastern Mediterranean region. Quat. Sci. Rev. 2018, 186, 236-262. [CrossRef]

33. Vakhrameeva, P.; Koutsodendris, A.; Wulf, S.; Fletcher, W.J.; Appelt, O.; Knipping, M.; Gertisser, R.; Trieloff, M.; Pross, J. The cryptotephra record of the Marine Isotope Stage 12 to 10 interval (460-335 ka) at Tenaghi Philippon, Greece: Exploring chronological markers for the Middle Pleistocene of the Mediterranean region. Quat. Sci. Rev. 2018, 200, 313-333. [CrossRef]

34. Mellis, O. Volcanic ash-horizons in deep-sea sediments from the eastern Mediterranean. Deep-Sea Res. 1954, 2, 89-92. [CrossRef]

35. Richardson, D.; Ninkovich, D. Use of $\mathrm{K}_{2} \mathrm{O}, \mathrm{Rb}, \mathrm{Zr}$, and $\mathrm{Y}$ versus $\mathrm{SiO}_{2}$ in volcanic ash layers of the eastern Mediterranean to trace their source. Bull. Geol. Soc. Am. 1976, 87, 110-116. [CrossRef]

36. Cita, M.B.; Vergnaud-Grazzini, C.; Robert, C.; Chamley, H.; Ciaranfi, N.; d'Onofrio, S. Paleoclimatic record of a long deep sea core from the eastern Mediterranean. Quat. Res. 1977, 8, 205-235. [CrossRef]

37. Keller, J.; Ryan, W.B.F.; Ninkovich, D.; Altherr, R. Explosive volcanic activity in the Mediterranean over the past 20,000 year as recorded in deep sea sediments. Geol. Soc. Am. Bull. 1978, 89, 591-604. [CrossRef]

38. Sparks, R.S.J.; Brazier, S.; Huang, T.C.; Muerdter, D. Sedimentology of the Minoan Deep-Sea Tephra layer in the Aegean and Eastern Mediterranean. Mar. Geol. 1983, 54, 131-167. [CrossRef] 
39. Vinci, A. Chemical differences between the island and submarine pumice layers of Thera. Mar. Geol. 1984, 55, 487-491. [CrossRef]

40. Narcisi, B.; Vezzoli, L. Quaternary stratigraphy of distal tephra layers in the Mediterranean-An overview. Global. Planet. Chang. 1999, 21, 31-50. [CrossRef]

41. Calanchi, N.; Cattaneo, A.; Dinelli, E.; Gasparotto, G.; Lucchini, F. Tephra layers in Late Quaternary sediments of the central Adriatic Sea. Mar. Geol. 1998, 149, 191-209. [CrossRef]

42. Siani, G.; Paterne, M.; Michel, E.; Sulpizio, R.; Sbrana, A.; Arnold, M.; Haddad, G. Mediterranean sea surface radiocarbon reservoir age changes since the Last Glacial Maximum. Science 2001, 294, 1917-1920. [CrossRef] [PubMed]

43. Siani, G.; Sulpizio, R.; Paterne, M.; Sbrana, A. Tephrostratigraphy study for the last $18,000{ }^{14} \mathrm{C}$ years in a deep-sea sediment sequence for the South Adriatic. Quat. Sci. Rev. 2004, 23, 2485-2500. [CrossRef]

44. Paterne, M.; Guichard, F.; Labeyrie, J.; Gillot, P.; Duplessy, J.C. Tyrrhenian Sea tephrochronology of the oxygen isotope record for the past 60,000 years. Mar. Geol. 1986, 72, 259-285. [CrossRef]

45. Paterne, M.; Guichard, F.; Labeyrie, J. Explosive activity of the South Italian volcanoes during the past 80,000 years as determined by marine tephrochronology. J. Volcanol. Geoth. Res. 1988, 34, 153-172. [CrossRef]

46. Insinga, D.D.; Tamburrino, S.; Lirer, F.; Vezzoli, L.; Barra, M.; De Lange, G.J.; Tiepolo, M.; Vallefuoco, M.; Mazzola, S.; Sprovieri, M. Tephrochronology of the astronomically-tuned KC01B deep-sea core, Ionian Sea: Insights into the explosive activity of the Central Mediterranean area during the last $200 \mathrm{ka}$. Quat. Sci. Rev. 2014, 85, 63-84. [CrossRef]

47. Crocitti, M.; Sulpizio, R.; Insinga, D.D.; De Rosa, R.; Donato, P.; Iorio, M.; Zanchetta, G.; Barca, D.; Lubritto, C. On ash dispersal from moderately explosive volcanic eruptions: Examples from Holocene and Late Pleistocene eruptions of Italian volcanoes. J. Volcanol. Geoth. Res. 2019, 385, 198-221. [CrossRef]

48. Tomlinson, E.L.T.; Smith, V.; Albert, P.G.; Aydar, E.; Civetta, L.; Cioni, R.; Çubukçu, E.; Gertisser, R.; Isaia, R.; Menzies, M.A.; et al. The major and trace element glass composition of the productive Mediterranean volcanic sources: Tools for correlating distal tephra layers in and around Europe. Quat. Sci. Rev. 2015, 118, 48-66. [CrossRef]

49. Hamann, Y.; Wulf, S.; Ersoy, O.; Ehrmann, W.; Aydar, E.; Schmiedl, G. First evidence of a distal early Holocene ash layer in Eastern Mediterranean deep-sea sediments derived from the Anatolian province. Quat. Res. 2010, 73, 497-506. [CrossRef]

50. Clift, P.; Blusztajin, J. The trace-element characteristics of Aegean and Aeolian volcanic arc tephra. J. Volcanol. Geoth. Res. 1999, 92, 321-347. [CrossRef]

51. Dacassou, E.; Capotanodi, L.; Murat, A.; Bernasconi, S.M.; Mulder, T.; Gonthier, E.; Migeon, S.; Duprat, J.; Giraudeau, J.; Mascale, J. Multiproxy Late Quaternary stratigraphy of the Nile deep-sea turbidite system-Towards a chronology of deep-sea terrigenous systems. Sediment. Geol. 2007, 200, 1-13. [CrossRef]

52. Allen, S.R.; Cas, R.A.F. Rhyolitic fallout and pyroclastic density current deposits from a phreatoplinian eruption in the eastern Aegean Sea, Greece. J. Volcanol. Geoth. Res. 1998, 86, 219-251. [CrossRef]

53. Allen, S.R.; Stadlbauer, E.; Keller, J. Stratigraphy of the Kos Plateau Tuff: Product of a major Quaternary explosive rhyolitic eruption in the eastern Aegean, Greece. Int. J. Earth Sci. 1999, 88, 132-156. [CrossRef]

54. Grant, K.M.; Rohling, E.J.; Bar-Matthews, M.; Ayalon, A.; Medina-Elizalde, M.; Bronk-Ramsey, C.; Satow, C.; Roberts, A.P. Rapid coupling between ice volume and polar temperature over the past 150,000 years. Nature 2012, 491, 744-747. [CrossRef]

55. Cane, T.; Rohling, E.J.; Kemp, A.E.S.; Cooke, S.; Pearce, R.B. High-resolution stratigraphic framework for Mediterranean sapropel S: Defining temporal relationship between records of Eemian climate variability. Palaeogeogr. Palaeoclimatol. Palaeoecol. 2002, 183, 87-101. [CrossRef]

56. Albert, P.G.; Smith, V.C.; Susuki, T.; Tomlinson, E.L.; Nakagawa, T.; Mclean, D.; Yamada, M.; Staff, R.A.; Schlolout, G.; Takemura, K.; et al. Constraints on the frequency and dispersal of explosive eruptions at Sambe and Daisen volcanoes (South-West Japan Arc) from the distal Lake Suigetsu record (SG06 core). Earth Sci. Rev. 2019, 185, 1004-1028. [CrossRef]

57. Wulf, S.; Keller, J.; Satow, C.; Gertisser, R.; Kraml, M.; Grant, K.M.; Appelt, O.; Vakhrameeva, P.; Koutsodendris, A.; Hardiman, M.; et al. Advancing Santorini's tephrostratigraphy: New glass geochemical data and improved marine-terrestrial tephra correlations for the past $\sim 360$ kyrs. Earth Sci. Rev. 2020, 200, 102964. [CrossRef] 
58. Tomlinson, E.L.; Kinvig, H.S.; Smith, V.C.; Blundy, J.D.; Gottsmann, J.; Müller, W.; Menzies, M.A. The Upper and Lower Nisyros Pumices: Revisions to the Mediterranean tephrostratigraphic record based on micron-beam glass geochemistry. J. Volcanol. Geoth. Res. 2012, 243-244, 69-80. [CrossRef]

59. Keller, J.; Gertisser, R.; Reusser, E.; Dietrich, V. Pumice deposits of the Santorini Lower Pumice 2 eruption on Anafi island Greece: Indications for a Plinian event of exceptional magnitude. J. Volcanol. Geoth. Res. 2014, 278, 120-128. [CrossRef]

60. Moller, T.; Schulz, H.; Hamann, Y.; Dellwig, O.; Kucera, M. Sedimentology and geochemistry of an exceptionally preserved last interglacial sapropel S5 in the Levantine Basin (Mediterranean Sea). Mar. Geol. 2012, 291, 34-48. [CrossRef]

61. Grant, K.M.; Rohling, E.J.; Bronk Ramsey, C.; Cheng, H.; Edwards, F.; Florindo, F.; Heslop, D.; Marra, F.; Roberts, A.P.; Tamisiea, M.E.; et al. Sea-level variability over five glacial cycles. Nat. Commun. 2014, 5, 5076. [CrossRef] [PubMed]

62. Emeis, K.C.; Robertson, A.H.F.; Richter, C. Shipboard crew of ODP leg 160. Chapter 8, Site 967. Proc. Ocean Drill. Program 1996, 160, 215-287.

63. Emeis, K.C.; Schulz, H.M.; Struck, U.; Sakamoto, T.; Doose, H.; Erlenkeuser, H.; Howell, M.; Kroon, D.; Paterne, M. Stable isotope and alkenone temperature records of sapropels from sites 964 and 967: Constraining the physical environment of sapropel formation in the eastern Mediterranean Sea. Proc. Ocean Drill. Program Sci. Results 1998, 160, 309-331.

64. Kroon, D.; Alexander, I.; Little, M.; Lourens, L.J.; Matthewson, A.; Robertson, A.H.F.; Sakamoto, T. Oxygen isotope and sapropel stratigraphy in the Eastern Mediterranean during the last 3.2 million years. Proc. Ocean Drill. Program 1998, 160, 181-189.

65. De Rijk, S.; Hayes, A.; Rohling, E.J. Eastern Mediterranean sapropel S1 interruption: An expression of the onset of climatic deterioration around 7 ka BP. Mar. Geol. 1999, 153, 337-343. [CrossRef]

66. Hayes, A.; Rohling, E.; De Rijk, S.; Kroon, D.; Zachariasse, W. Mediterranean planktonic foraminiferal faunas during the last glacial cycle. Mar. Geol. 1999, 153, 239-252. [CrossRef]

67. Hieke, W.; Hemleben, C.; Linke, P.; Türkay, M.; Weikert, H. Mittelmeer 1998/99, Cruise No. 40, 28 October 1997-10 February 1998Mittelmeer 1998. In METEOR-Berichte; Universität Hamburg: Hamburg, Germany, 1999; p. 286.

68. Blockley, S.P.E.; Pyne-O’Donnel, S.; Lowe, J.J.; Matthews, I.P.; Stone, A.; Pollard, A.M.; Turney, C.S.M.; Molyneux, E.G. A new and less destructive laboratory procedure for the physical separation of distal glass shards from sediments. Quat. Sci. Rev. 2005, 24, 1952-1960. [CrossRef]

69. Jochum, K.P.; Stoll, B.; Herwig, K.; Willbold, M.; Hofmann, A.W.; Amini, M.; Aarburg, S.; Abouchami, W.; Hellebrand, E.; Mocek, B.; et al. MPI-DING reference glasses for in situ microanalysis: New reference values for element concentrations and isotope ratios. Geochem. Geophys. Geosyst. 2006, 7. [CrossRef]

70. Pearce, N.J.S.; Bendall, C.A.; Westgate, J.A. Comment on "Some numerical considerations in the geochemical analysis of distal microtephra" by A.M. Pollard, S.P.E. Blockley and C.S. Lane. Appl. Geochem. 2008, 23, 1353-1364. [CrossRef]

71. Hunt, J.B.; Hill, P.G. An inter-laboratory comparison of the electron probe microanalysis of glass geochemistry. Quat. Int. 1996, 34, 229-241. [CrossRef]

72. Kuehn, S.C.; Froese, D.G.; Shane, P.A.R. INTAV Intercomparison Participants. The INTAV intercomparison of electron-beam microanalysis of glass by tephrochronology laboratories: Results and recommendations. Quat. Int. 2011, 246, 19-47. [CrossRef]

73. Aitchison, J.; Barcelo-Vidal, C.; Pawlowsky-Glahn, V. Some comments on compositional data analysis in archaeometry, in particular the fallacies in Tangri and Wright's dismissal of logratio analysis. Archaeometry 2002, 44, 295-304. [CrossRef]

74. Pollard, A.M.; Blockley SP, E.; Lane, C.S. Some numerical considerations in the geochemical analysis of distal microtephra. Appl. Geochem. 2006, 21, 1692-1714. [CrossRef]

75. Hammer, Ø.; Harper, D.A.T.; Ryan, P.D. PAST: Paleontological statistics software package for education and data analysis. Palaeontol. Electron. 2001, 4,1-9. Available online: https://palaeo-electronica.org/2001_1/past/ issue1_01.htm (accessed on 12 March 2020).

76. Ryan, P.D.; Hammer, Ø.; Harper, D.A.; Paul Ryan, D.D. PAST: Paleontological Statistics Software Package for Education and Data Analysis; Geological Museum: Copenhagen, Denmark, 2001; Available online: https://omictools.com/past-2-tool (accessed on 12 March 2020). 
77. Le Bas, M.J.; Le Maitre, R.W.; Streckeisen, A.; Zanettin, B. A chemical classification of volcanic rocks based on the total alkali-silica diagram. J. Petrol. 1985, 27, 745-750. [CrossRef]

78. Schmincke, H.U.; Sumita, M. Impact of volcanism on the evolution of Lake Van (eastern Anatolia) III: Periodic (Nemrut) vs. episodic (Süphan) explosive eruptions and climate forcing reflected in a tephra gap between ca. 14 ka and ca. 30 ka. J. Volcanol. Geoth. Res. 2014, 285, 195-213. [CrossRef]

79. Tryon, C.A.; Logan, M.A.V.; Mouralis, D.; Kuhn, S.; Slimak, L.; Balkan-Atli, N. Building a tephrostratigraphic framework for the Paleolithic of Central Anatolia, Turkey. J. Archaeol. Sci. 2009, 36, 637-652. [CrossRef]

80. Menzel, D.; Schouten, S.; van Bergen, P.F.; Sinninghe Damsteé, J.S. Higher plant vegetation changes during Pliocene sapropel formation. Org. Geochem. 2004, 35, 1343-1353. [CrossRef]

81. Kataoka, K.S.; Urabe, A.; Nagahashi, Y. Millennial-scale reworking of tephra in alluvial to shallow marine settings: Distinguishing pseudo-isochrons from genuine ones. Quat. Int. 2016, 397, 173-193. [CrossRef]

82. Druitt, T.H.; Edwards, L.; Mellors, R.A.A.; Pyle, D.M.; Sparks, R.S.J.; Lanphere, M.; Davies, M.; Barriero, B. Santorini Volcano. Geol. Soc. Mem. 1999, 19. Available online: https://pubs.er.usgs.gov/publication/70094778 (accessed on 5 March 2020).

83. Vespa, M.; Keller, J.; Gertisser, R. Interplinian explosive activity of Santorini volcano (Greece) during the past 150,000 years. J. Volcanol. Geoth Res. 2006, 153, 262-286. [CrossRef]

84. Volentik, A.; Vanderkluysen, L.; Principe, C. Stratigraphy of the Caldera walls of Nisyros volcano, Greece. Eclogae Geolgicae Helv. 2002, 95, 223-235.

85. Bachmann, O.; Schoene, B.; Schnyder, C.; Spikings, R. The ${ }^{40} \mathrm{Ar} /{ }^{39} \mathrm{Ar}$ and U/Pb dating of young rhyolites in the Kos-Nisyros volcanic complex, Eastern Aegean Arc, Greece: Age discordance due to excess ${ }^{40} \mathrm{Ar}$ in biotite. Geochem. Geophys. Geosyst. 2010, 11. [CrossRef]

86. Bachmann, O.; Deering, C.D.; Ruprecht, J.S.; Huber, C.; Skopelitis, A.; Schnyder, C. Evolution of silicic magmas in the Kos-Nisyros volcanic center, Greece: Cycles associated with caldera collapse. Contrib. Mineral. Petrol. 2012, 163, 151-166. [CrossRef]

87. Klaver, M.; Mateev, S.; Berndt, J.; Lissenberg, C.J.; Vroon, P.Z. A mineral and cumulate perspective to magma differentiation at Nisyros volcano, Aegean arc. Contrib. Mineral. Petrol. 2017, 172, 95. [CrossRef]

88. Bachmann, O.; Wallace, P.J.; Bourquin, J. The melt inclusion record from the rhyolitic Kos Plateau Tuff (Aegean Arc). Contrib. Mineral. Petrol. 2010, 159, 187-202. [CrossRef]

89. Kuzucuoglu, C.; Pastre, J.-F.; Black, S.; Ercan, T.; Fontugne, M.; Guillou, H.; Hatté, C.; Karabiyikoglu, M.; Orth, P.; Türkecan, A. Identification and dating of tephra layers from Quaternary sedimentary sequences of Inner Anatolia, Turkey. J. Volcanol. Geoth. Res. 1998, 85, 152-172. [CrossRef]

90. Giaccio, B.; Niespolo, E.M.; Pereira, A.; Nomade, S.; Renne, P.R.; Albert, P.G.; Arienzo, I.; Regattieri, E.; Wagner, B.; Zanchetta, G.; et al. First integrated tephrochronological record for the last $190 \mathrm{kyr}$ from the Fucino Quaternary lacustrine succession, central Italy. Quat. Sci. Rev. 2017, 158, 211-234. [CrossRef]

91. Bar-Matthews, M.; Ayalon, A.; Gilmour, M.; Matthews, A.; Hawkesworth, C.J. Sea-land oxygen isotopic relationships from planktonic foraminifera and speleothems in the Eastern Mediterranean region and their implication for paleo rainfall during interglacial intervals. Geochim. Cosmochim. Acta 2003, 67, 3181-3199. [CrossRef]

92. Giaccio, B.; Nomade, S.; Wulf, S.; Isaia, R.; Sottili, G.; Cayuoto, G.; Galli, P.; Messina, P.; Sposato, A.; Sulpizio, R.; et al. The late MIS 5 Mediterranean tephra markers: A reappraisal from peninsular Italy terrestrial records. Quat. Sci. Rev. 2012, 56, 31-45. [CrossRef]

93. Leicher, N.; Zanchetta, G.; Sulpizio, R.; Giaccio, B.; Wagner, B.; Nomade, S.; Francke, A.; Del Carlo, P. First tephrostratigraphic results of the DEEP site record from Lake Ohrid (Macedonia and Albania). Biogeosciences 2016, 13, 2151-2178. [CrossRef]

94. Marino, G.; Rohling, E.J.; Rodríguez-Sanz, L.; Grant, K.M.; Heslop, D.; Roberts, A.P.; Stanford, J.D.; Yu, J. Bipolar seesaw control on last interglacial sea level. Nature 2015, 522, 197-201. [CrossRef]

(C) 2020 by the authors. Licensee MDPI, Basel, Switzerland. This article is an open access article distributed under the terms and conditions of the Creative Commons Attribution (CC BY) license (http://creativecommons.org/licenses/by/4.0/). 